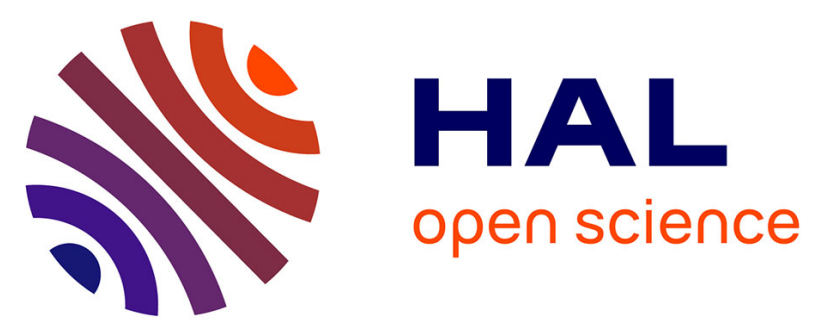

\title{
The internal deformation of the Peridotite Nappe of New Caledonia: a structural study of serpentine-bearing faults and shear zones in the Koniambo Massif
}

Benoît Quesnel, Pierre Gautier, Michel Cathelineau, Philippe Boulvais, Clément Couteau, Maxime Drouillet

\section{- To cite this version:}

Benoît Quesnel, Pierre Gautier, Michel Cathelineau, Philippe Boulvais, Clément Couteau, et al.. The internal deformation of the Peridotite Nappe of New Caledonia: a structural study of serpentinebearing faults and shear zones in the Koniambo Massif. Journal of Structural Geology, 2016, 85, pp.51-67. 10.1016/j.jsg.2016.02.006 . insu-01278589

\section{HAL Id: insu-01278589 \\ https://hal-insu.archives-ouvertes.fr/insu-01278589}

Submitted on 24 Feb 2016

HAL is a multi-disciplinary open access archive for the deposit and dissemination of scientific research documents, whether they are published or not. The documents may come from teaching and research institutions in France or abroad, or from public or private research centers.
L'archive ouverte pluridisciplinaire HAL, est destinée au dépôt et à la diffusion de documents scientifiques de niveau recherche, publiés ou non, émanant des établissements d'enseignement et de recherche français ou étrangers, des laboratoires publics ou privés. 


\section{Accepted Manuscript}

The internal deformation of the Peridotite Nappe of New Caledonia: a structural study of serpentine-bearing faults and shear zones in the Koniambo Massif

Benoît Quesnel, Pierre Gautier, Michel Cathelineau, Philippe Boulvais, Clément Couteau, Maxime Drouillet

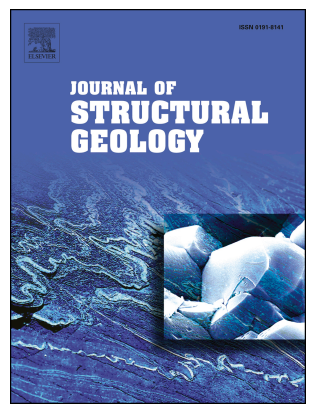

PII: S0191-8141(16)30015-3

DOI: 10.1016/j.jsg.2016.02.006

Reference: $\quad$ SG 3309

To appear in: Journal of Structural Geology

Received Date: 11 January 2016

Revised Date: 17 February 2016

Accepted Date: 20 February 2016

Please cite this article as: Quesnel, B., Gautier, P., Cathelineau, M., Boulvais, P., Couteau, C., Drouillet, M., The internal deformation of the Peridotite Nappe of New Caledonia: a structural study of serpentinebearing faults and shear zones in the Koniambo Massif, Journal of Structural Geology (2016), doi: 10.1016/j.jsg.2016.02.006.

This is a PDF file of an unedited manuscript that has been accepted for publication. As a service to our customers we are providing this early version of the manuscript. The manuscript will undergo copyediting, typesetting, and review of the resulting proof before it is published in its final form. Please note that during the production process errors may be discovered which could affect the content, and all legal disclaimers that apply to the journal pertain. 
The internal deformation of the Peridotite Nappe of New Caledonia: a structural study of serpentine-bearing faults and shear zones in the Koniambo Massif

3

Benoît Quesnel ${ }^{1}$, Pierre Gautier ${ }^{1}$, Michel Cathelineau ${ }^{2,}$ Philippe Boulvais ${ }^{1}$, Clément Couteau ${ }^{3}$, Maxime Drouillet ${ }^{3}$

${ }^{1}$ Université Rennes 1, CNRS, Géosciences Rennes UMR 6118, OSUR, 35042 Rennes Cedex, France, benoit.quesnel@univ-rennes1.fr; pierre.gautier@univ-rennes1.fr; philippe.boulvais@univ-rennes1.fr

${ }^{2}$ Université de Lorraine, CNRS, CREGU, GeoRessources lab., 54506 Vandoeuvre-lèsNancy, France, michel.cathelineau@univ-lorraine.fr

${ }^{3}$ Service géologique, Koniambo Nickel SAS, 98883 Voh, Nouvelle Calédonie, mdrouillet@koniambonickel.nc

Keywords : New Caledonia, ophiolite, serpentine, magnesite, nappe, structural analysis

\section{Abstract}

We present a structural analysis of serpentine-bearing faults and shear zones in the Koniambo Massif, one of the klippes of the Peridotite Nappe of New Caledonia. Three structural levels are recognized. The upper level is characterized by a dense network of fractures. Antigorite and polygonal serpentine form slickenfibers along fault planes with distinct kinematics. As a result, the upper level keeps the record of at least two deformation events, the first associated with the growth of antigorite (WNW-ESE extension), the second with the growth of polygonal serpentine (NW-SE compression). The lower level coincides with the 'serpentine sole' of the nappe, which consists of massive tectonic breccias overlying a layer of mylonitic serpentinites. The sole records pervasive tangential shear with top-to-SW kinematics and represents a décollement at the base of the nappe. The intermediate level is characterized by 
the presence of several meters-thick conjugate shear zones accommodating NE-SW

28 shortening. Like the sole, these shear zones involve polygonal serpentine and magnesite as the main syn-kinematic mineral phases. The shear zones likely root into the basal décollement, either along its roof or, occasionally, around its base. Compared to top-to-SW shearing along the sole, the two deformation events recorded in the upper level are older. in the degree of serpentinization. It is therefore tempting to consider that the intensity of serpentinization played a major role in the way deformation has been distributed across the Peridotite Nappe. However, even the least altered peridotites, in the upper level, contain so much serpentine that, according to theoretical and experimental work, they should be nearly as weak as pure serpentinite. Hence, no strong vertical gradient in strength due to variations in the degree of serpentinization is expected within the exposed part of the nappe. Our proposal is that strain localization along the serpentine sole results from the juxtaposition of the nappe, made of weak serpentinized peridotites, against the strong mafic rocks of its substratum. This interpretation is at odds with the intuitive view that would consider the nappe, made of peridotites, as stronger than its basement.

\section{Introduction}

Ophiolites commonly occur within orogenic belts as a result of the obduction of a piece of oceanic lithosphere upon a continental basement (Coleman, 1971; Dewey and Bird, 1971). The ultramafic rocks that constitute a large part of most ophiolitic nappes generally display evidence for pronounced fluid-rock interactions in the form of a spatially uneven development of serpentinization. Due to their low strength in comparison to peridotites (e.g., Escartín et al., 2001), serpentinites have the capacity to promote strain localization and greatly influence the style of deformation on the lithosphere scale (e.g., Hirth and Guillot, 2013). Several types of serpentine may be identified in a single ophiolite, which raises the question of their relative 
52 chronology and their geodynamic environment of formation (e.g., Coulton et al., 1995). The

53 topic of this work is on ophiolitic nappes remaining near the surface, thus excluding the case

54 of dismembered meta-ophiolitic sequences occasionally exposed in the internal zones of 55 orogenic belts. In principle, serpentinization within an ophiolitic nappe may witness the successive stages of oceanic accretion, intra-oceanic subduction (the ophiolite lying in the upper plate, for instance in the fore-arc region), obduction, and post-obduction evolution. Post-obduction events may involve post-convergence extension and/or collisional orogeny. Nappe hosts various types of serpentine (Lahondère and Maurizot, 2009; Ulrich, 2010; Lahondère et al., 2012). An intimate association between deformation and the occurrence of serpentines is recognized in these studies, however no attempt has been made so far to characterize this deformation. More generally, structural studies carried out on the ultramafic section of ophiolitic nappes usually focus on serpentine-free high grade fabrics (e.g., Boudier et al., 1988; Suhr and Cawood, 1993; Cook et al., 2000). Studies including an analysis of serpentine-bearing faults and shear zones are relatively rare (Bailey et al., 2000; Titus et al., 2002; Schemmann et al., 2007; Laó-Dávila and Anderson, 2009; Federico et al., 2014).

In New Caledonia, earlier studies concerned with the Peridotite Nappe have focused on i) the high temperature intra-oceanic stages of deformation within the nappe (Prinzhofer et al., 1980; Titus et al., 2011), ii) the obduction process, however based essentially on the analysis of the rock units underlying the nappe (e.g., Cluzel et al., 2001, 2012; Spandler et al., 2005; Lagabrielle et al., 2013) and iii) post-obduction brittle extension that shaped the island as a large horst (e.g., Lagabrielle et al., 2005; Chardon and Chevillotte, 2006). Furthermore, much attention has been put on the chemistry and mineralogy of thick lateritic profiles formed at the expense of the peridotites, which led to the development of worldclass nickel 
mineralizations (e.g., Orloff, 1968; Trescases, 1975; Butt and Cluzel, 2013). In contrast, only limited work has concerned serpentines-bearing faults and shear zones that are ubiquitous throughout the Peridotite Nappe, despite the common statement that the distribution of nickel ore is highly dependent on this fault network (Leguéré, 1976; Cluzel and Vigier, 2008).

In this study, we had access to a recently opened large mining site in the Koniambo Massif, one of the klippes of the Peridotite Nappe in northwestern New Caledonia (Fig. 1). This site provides a quasi-continuous exposure of fresh rocks from the base of the nappe, near sea level, up to $\sim 800 \mathrm{~m}$ elevation, where the main laterite capping the peridotites occurs. We focused on the study of structures and deformation associated with serpentines. These data enable to describe the internal deformation of the nappe in relation with successive serpentinization events. The implications of this study for the tectonic evolution of New Caledonia are not discussed here and will be the topic of a distinct paper.

\section{Geological setting}

New Caledonia is located in the southwest Pacific Ocean, $1300 \mathrm{~km}$ east of Australia (Fig. 1). On the main island, known as the "Grande Terre", the Peridotite Nappe overlies, with a subhorizontal tectonic contact (Avias, 1967; Guillon, 1975), a substratum composed of several volcano-sedimentary units (Paris, 1981; Cluzel et al., 2001, 2012). The Peridotite Nappe is essentially exposed in the "Massif du Sud", covering much of the southeastern third of the Grande Terre, and as a series of klippes along the northwestern coast (Fig. 1). In the Massif du Sud, the thickness of the nappe is at least $1.5 \mathrm{~km}$ and may reach $3.5 \mathrm{~km}$ (Guillon, 1975). The nappe is mostly composed of harzburgites except in the northernmost klippes where lherzolites dominate (e.g., Ulrich et al., 2010). Compositional layering is essentially represented by 1 to $100 \mathrm{~m}$-thick layers of dunite within the harzburgites. In the main part of the nappe, the degree of serpentinization of the peridotites is variable but moderate (Orloff, 1968), serpentines occurring preferentially along a network of $\mathrm{mm}$ - to $\sim 10 \mathrm{~cm}$-thick fractures 
103 and shear zones (e.g., Leguéré, 1976; Lahondère and Maurizot, 2009; Lahondère et al., 2012).

104 Fracture infillings and veins with various textures are described, containing 105 lizardite \pm chrysotile or antigorite \pm chrysotile and/or an additional type of light-coloured 106 serpentine not firmly identified (Lahondère and Maurizot, 2009; Lahondère et al., 2012). 107 Serpentinization becomes pervasive along the base of the nappe, forming a 'sole' in which 108 deformation has been intense (Avias, 1967; Orloff, 1968; Guillon, 1975; Leguéré, 1976; 109 Cluzel et al., 2012; Quesnel et al., 2013). The thickness of this sole is a few tens of meters in 110 the Massif du Sud but reaches a few hundred meters in the northwestern klippes (Guillon, 111 1975; Maurizot et al., 2002). According to Ulrich (2010), serpentinization of the sole involved 112 three stages, firstly a pervasive development of lizardite, secondly the formation of antigorite 113 within $\mathrm{mm}$ to $\mathrm{cm}$-thick veins, finally the formation of chrysotile in local veinlet networks. In 114 some of the veinlets, Ulrich (2010) also reports the partial replacement of chrysotile by 115 polygonal serpentine. Recently, Ulrich et al. (2014) established that polygonal serpentine is 116 more widespread in the sole than previously thought, forming light green serpentine veins 117 associated with chrysotile veinlets.

118 Following their exposure to aerial conditions, the peridotites have been subject to 119 intense weathering under dominantly warm and wet climatic conditions. This has led to the 120 development of laterites up to $\sim 30 \mathrm{~m}$ thick (e.g., Chevillotte et al., 2006). Leaching of the 121 peridotites by downward infiltrating meteoric waters has resulted in a redistribution of 122 elements, leading to high nickel concentrations at the base of the weathering profile, in the 123 transition zone between coarse-grained saprolite and the bedrock (Orloff, 1968; Trescases, 124 1975; Leguéré, 1976; Paris, 1981). Some veins with nickel-rich mineralizations show 125 evidence for a syn-tectonic emplacement (Cluzel and Vigier, 2008). Magnesite veins, which 126 frequently occur along the serpentine sole of the Peridotite Nappe, represent another by127 product of the leaching of the peridotites by meteoric fluids (Ulrich, 2010; Quesnel et al., 2013). Quesnel et al. (2013) showed that at least some of these veins have been emplaced 
during pervasive shearing along the sole.

In the Koniambo Massif, the Peridotite Nappe is exposed from its base, near sea level, up to $\sim 800$ m elevation (Fig. 2a,b). Map relations (Carroué, 1972; Maurizot et al., 2002) show that the basal contact is subhorizontal around much of the massif but delineates a large open antiform in the west (Fig. 2b). At elevations above $~ 400 \mathrm{~m}$, the nappe is capped by a highly dissected and partly reworked lateritic profile (Maurizot et al., 2002). At lower elevations, laterites of the westerly-inclined Kaféaté plateau probably belong to a younger planation surface (Latham, 1977; Chevillotte et al., 2006). The Koniambo Massif essentially consists of harzburgites with interlayers of dunite that define a crude compositional layering with a fairly regular ENE-WSW strike and a $\sim 50^{\circ}$ southward dip (Maurizot et al., 2002). With regard to the degree of serpentinization, Maurizot et al. (2002) distinguished three main rock types, namely (i) moderately serpentinized peridotites in which the primary compositional layering is preserved, (ii) highly serpentinized peridotites and (iii) massive serpentinites. The latter form the serpentine sole of the nappe, about $200 \mathrm{~m}$ thick. The highly serpentinized peridotites overlie the sole and form a distinct layer which, according to Maurizot et al. (2002), is 200 $m$ thick on the western flank of the massif but thins out further east (Fig. 2a,b). The moderately serpentinized peridotites occupy the higher part of the massif.

\section{Methods}

\subsection{Strategy}

Field work focused on fresh rock exposures provided by the last $\sim 5$ years of mining activity in the Koniambo Massif. The serpentine sole is well exposed in the Vavouto peninsula, especially along two cross-sections here named VA1 (700 m long, striking N082 ${ }^{\circ}$, Fig. 2c) and VA2 (a composite section $~ 330$ m long with a mean N-S strike). The VA2 section shows the basal contact of the nappe and its substratum made of basalts and minor cherts (Fig. 3a). Further east, the mine access road runs from the base of the nappe (height spot $65 \mathrm{~m}$ in Figure 
154 2a) to the upper part of the massif; it provides good outcrops of the intermediate level of

155 highly serpentinized peridotites. The moderately serpentinized peridotites are exposed at

156 higher levels of the access road and in a series of currently exploited open pits. We carried out

157 preliminary field observations and sampled rocks with various textures and fabrics (veins,

158 fracture infillings, fault coatings, cleavage domains within shear zones). We determined the

159 mineralogical content of the samples, which then served as references for macroscopic

160 assessment of the mineralogy within specific structures during renewed field work and

161 structural analysis.

162 3.2. Analytical methods

163 Reference samples have been characterized through a multi-technique approach including

164 transmission electron microscopy, microprobe analysis (not presented here) and Raman

165 spectroscopy. Raman spectroscopy measurements were carried out at the laboratory

166 GéoRessources Nancy, France, using a Horiba Jobin-Yvon Labram HR800 spectrometer and

167 a visible ionized argon laser source with a wavelength of $514 \mathrm{~nm}$. The output power of the

168 laser was $100 \mathrm{~mW}$ and measurements were performed using an Olympus lens of x50 to focus

169 the laser beam onto an area $1 \mu \mathrm{m}$ in diameter. Spectra are the average of 6 to 10 acquisitions

170 of $20 \mathrm{~s}$ each to optimize the signal/noise ratio. For serpentine identification, only one region

171 of the Raman spectrum has been investigated, between $3520 \mathrm{~cm}^{-1}$ and $3870 \mathrm{~cm}^{-1}$ (Fig. 4). This

172 region enables to characterize the hydroxyl groups which are the most discriminant for

173 distinguishing the polymorphs of serpentine (Auzende et al., 2004; Schwartz et al., 2013;

$174 \quad$ Ulrich et al., 2014).

For analyzing the deformation, we focused our attention on shear zones and fault

176 planes. The kinematics of shear zones have been determined using the obliquity of cleavage

177 with respect to the shear zone walls (Fig. 5e,f) and, occasionally, the occurrence of a set of

178 oblique shear bands. For determining the kinematics of faults, the offset of pre-kinematic 
markers or the presence of subsidiary Riedel shears has occasionally been used, however in most cases we favoured the use of accreted slickenfibers with a clear staircase geometry (Fig. 5a,b,c,d). The advantage of stepped slickenfibers is to provide a robust sense-of-slip indicator and to allow establishing which mineral or mineral assemblage was stable during a given fault slip event (Durney and Ramsay, 1973; see also, e.g., Twiss and Moores, 1992). software of Allmendinger et al. (2012). The basic tenets of this software, described by Marrett and Allmendinger (1990), are the same as those of the right-dihedra method (Angelier and Mechler, 1977; Angelier, 1994). It should be noticed that the approach used by Marrett and Allmendinger (1990) is intended to provide a qualitative description of the strain ellipsoid, not the stress ellipsoid. Several authors have argued that, in essence, the analysis of fault slip data informs more about strain than about stress (e.g., Twiss and Unruh, 1998; Tikoff and Wojtal, 1999; Gapais et al., 2000). According to Célérier et al. (2012), methods aiming at retrieving

192 paleostresses may be more suited for separating distinct subsets (presumed to witness 193 successive tectonic events) within a given fault slip dataset whereas methods aiming at 194 retrieving strain (e.g., Marrett and Allmendinger, 1990) may be more suited for yielding an 195 average estimate of strain within a rock volume. In our case, the mineralogy of slickenfibers, 196 which is of two types, has provided an independent criterion for separating the fault slip data 197 into two subsets, therefore the 'strain' approach seems more appropriate.

\section{4. Results}

\subsection{Reference samples}

200 We here describe three hand specimens that are representative of field cases where serpentine 201 occurs in association with deformation. The two first specimens come from higher levels of 202 the Koniambo Massif. The third sample comes from the Vavouto peninsula, within the 203 serpentine sole. 
The first sample includes a $\sim \mathrm{cm}$-thick vein of light olive green serpentine with a massive aspect (Fig. 4a). The vein has been active as a fault plane as indicated by fine striations underlined by black oxides along a surface parallel to its margin. The Raman spectrum of the vein material (analysis \#1-1) shows two closely spaced main bands centered on $\sim 3688 \mathrm{~cm}^{-1}$ and $\sim 3694 \mathrm{~cm}^{-1}$, which are diagnostic of polygonal serpentine (Auzende et al., 2004; Ulrich, 2010; Ulrich et al., 2014).

The second sample includes a $\sim 1 \mathrm{~cm}$-thick vein of platy-fibrous serpentine (Fig. 4b).

Outside the vein, the host rock shows a Raman spectrum (\#2-1) with two main bands centered on $\sim 3688 \mathrm{~cm}^{-1}$ and $\sim 3696 \mathrm{~cm}^{-1}$, indicating the presence of polygonal serpentine. The vein itself is composite. Two insulated domains with diffuse boundaries are made of darker serpentine showing a Raman spectrum (\#2-2) with two main bands centered on $\sim 3672 \mathrm{~cm}^{-1}$ and $\sim 3700 \mathrm{~cm}^{-1}$, typical for antigorite. The main part of the vein appears as an heterogeneous stack of fibers. The Raman spectrum of analysis \#2-3 in this domain shows a minor band centered on $\sim 3671 \mathrm{~cm}^{-1}$, attesting for the presence of antigorite. In addition, the main band centered on $\sim 3698 \mathrm{~cm}^{-1}$ and the adjacent poorly developed band at $\sim 3688 \mathrm{~cm}^{-1}$ indicate the presence of polygonal serpentine or/and chrysotile. Finally, the margin of the vein is underlined by small domains of homogeneous light green serpentine. Their staircase distribution indicates that they formed as the result of a fault slip event. The Raman spectrum 222 of analysis \#2-4 shows a main band centered on $\sim 3697 \mathrm{~cm}^{-1}$ and an adjacent poorly developed 223 band at $\sim 3690 \mathrm{~cm}^{-1}$ which, again, points to the presence of polygonal serpentine or/and 224 chrysotile. In that case, however, chrysotile is unlikely because the serpentine in this part of 225 the vein is massive and does not display the habitus of well defined submillimetric fibers that 226 is typical for chrysotile (Lahondère and Maurizot, 2009; Ulrich, 2010; Lahondère et al., 227 2012). The small domains of polygonal serpentine have well defined boundaries, which 228 suggests that they formed later than the adjacent domain of darker antigorite did. Furthermore, the platy-fibrous nature of the main part of the vein is typical for antigorite (e.g., 
230 Lahondère et al., 2012), therefore the occasional intimate association of antigorite and

231 polygonal serpentine, like in analysis \#2-3, can be interpreted as the result of a partial 232 pseudomorphosis of antigorite by fine-grained polygonal serpentine. Thus, the crystallization 233 of polygonal serpentine appears to postdate that of antigorite.

The third sample consists of a fist-sized elongate clast taken from one of the major 235 shear zones met along the VA1 section (Fig. 2c). The clast, which is made of pervasively 236 serpentinized harzburgite with few orthopyroxene relics, is embedded in a film up to $0.5 \mathrm{~cm}$ 237 thick of homogeneous pale green serpentine (Fig. 4c,d). The Raman spectrum (analysis \#3-1) 238 shows two closely spaced main bands centered on $\sim 3691 \mathrm{~cm}^{-1}$ and $~ 3697 \mathrm{~cm}^{-1}$, indicating that 239 the film consists of polygonal serpentine.

240 4.2. Field determination of the serpentine polymorphs associated with deformation

241 Based on the characterization of the three above samples as well as other reference samples, 242 we have established a number of macroscopic criteria for a field assessment of the mineralogy 243 of fault zones and shear zones. Within fault zones, antigorite and polygonal serpentine are 244 both able to build macroscopic slickenfibers with a clear staircase geometry. For 245 distinguishing the two polymorphs, the main argument is textural. Antigorite has a well 246 expressed platy-fibrous aspect (see also, e.g., Lahondère et al., 2012) with fibers frequently 247 several centimeters long (Fig. 5a). In contrast, polygonal serpentine is massive, matte, and 248 develops only short slickenfibers (Fig. 5b,c). A second argument is the fact that polygonal 249 serpentine is pale green whereas antigorite is generally darker (Figs. 4b,c,d and 5a,b,c). 250 However, in the saprolitic levels, weathering modifies the colours and polygonal serpentine 251 tends to become olive green (Figs. $4 \mathrm{a}$ and 5c). In addition, some fault planes bear 252 slickenfibers showing mixed properties, with a clear platy-fibrous nature but a pale green 253 colour and a matte aspect (Fig. 5d). In that case, taking into account the likeliness of a 254 pseudomorphic replacement of antigorite by polygonal serpentine, as in the second reference 
sample above, we have assumed that the slickenfibers witness a syn-antigorite slip event.

Antigorite and polygonal serpentine are also involved in shear zones. There, antigorite forms distinct lamellae (Fig. 5e) whereas polygonal serpentine is more massive despite the development of a pronounced cleavage (Fig. 5f). Most of the shear zones we have observed involve polygonal serpentine. There is always a close spatial coincidence between the shear zone walls and the margins of the serpentine body (Fig. 5e,f). The fabric in each shear zone is pronounced and, in principle, shearing might post-date serpentinization. Nevertheless, would shearing occur under physical conditions outside the stability range of a primary serpentine, it

263 is expected that a new serpentine polymorph would easily crystallize during the pervasive 264 deformation. Hence, for shear zones with an homogeneous serpentine content, we assume that 265 shearing and mineral growth were coeval.

Lizardite and chrysotile were also observed in the field, with features similar to those reported by Ulrich (2010) and Lahondère et al. (2012). Dark lizardite is widespread, present as a diffuse grain-scale network in the peridotites and as infillings of $\sim 1 \mathrm{~mm}$ to $\sim 5 \mathrm{~cm}$-wide joints. It is also found on the margins of many of the faults and shear zones that involve antigorite or polygonal serpentine (Fig. 5c,e). However, lizardite itself only rarely bears

271 striations and, in our experience, never builds macroscopic slickenfibers, therefore we made no attempt to characterize the deformation associated with lizardite. Chrysotile occurs as very

273 thin fibers always oriented at right angle to the vein walls within $\leq 1 \mathrm{~cm}$-thick veinlets. Dense 274 networks of subparallel veinlets are locally observed. Such veins can be interpreted as tension 275 gashes, therefore, in principle, they could provide some clue on the tectonic regime that 276 prevailed during chrysotile growth. Alternatively, tension gashes may open in the absence of 277 a significant tectonic contribution, for instance due to fracturing assisted by fluid pressure. 278 For this reason, and because these thin veins represent very small amounts of strain, we 279 ignored them during the analysis of deformation. 
We identified three structural levels, which correlate with the rock horizons identified by Maurizot et al. (2002) on the basis of the intensity of serpentinization (Fig. 2a,b).

\subsubsection{Upper structural level}

The Upper structural level coincides with the domain of moderately serpentinized

peridotites at higher levels of the massif. A dense network of fractures, most of them dipping steeply, crosscut the peridotites (Fig. 6a). The spacing between adjacent macroscopic fractures is always less than $\sim 2 \mathrm{~m}$. In between fractures, the least serpentinized peridotites show 'mesh' textures (e.g., Rouméjon and Cannat, 2014) resulting from a partial replacement of olivine by lizardite along grain boundaries and grain-scale microfractures (Fig. 6b). On the outcrop scale, in addition to 'dry' joints, many fractures are filled with one or several types of

291 serpentine. When present together with another serpentine polymorph, lizardite occupies the margins of the fracture (Fig. 5c). When occurring together, antigorite and polygonal serpentine occupy the core vs. the margins of the fracture, respectively. As discussed with the second reference sample in Section 4.1 (Fig. 4b), polygonal serpentine formed later.

In most veins involving fibrous polygonal serpentine or/and antigorite, the fibers lie at a very low angle to the vein walls, hence these veins can be interpreted as fault zones (e.g., Durney and Ramsay, 1973). A total of 125 such faults has been measured in a series of open pits covering a relatively small area on the top of the Koniambo Massif (Fig. 2a). The synpolygonal serpentine vs. syn-antigorite nature of each fault displacement has been determined by assessing the mineralogy of associated slickenfibers (Fig. 5a,b,c,d) (see Section 4.2). As a result, two fault subsets have been defined, which compare well in terms of orientation but have distinct kinematics (Fig. 7a,b). The majority of the faults with dominantly dip-slip movement have a normal sense of slip when associated with antigorite vs. a reverse sense of slip when associated with polygonal serpentine. Fault slip analysis documents two strikingly 
different strain ellipsoids (Fig. 7c,d). The syn-antigorite faults yield a highly constrictional

ellipsoid, as illustrated by the value of 0.17 computed for the $\mathrm{R}$ ratio $\left(\mathrm{R}=\left(\varepsilon_{2}-\varepsilon_{3}\right) /\left(\varepsilon_{1}-\varepsilon_{3}\right)\right)$.

307 Consequently, $\lambda_{1}$, the axis of maximum stretching, is the most accurately defined; it lies

308 horizontally with a $\mathrm{N} 102^{\circ}$ trend (Fig. 7c). The axis of maximum shortening, $\lambda_{3}$, plunges

309 steeply $\left(64^{\circ}\right)$ to the north-northeast. The syn-polygonal serpentine faults yield an ellipsoid in

310 the flattening field $(\mathrm{R}=0.71)$. Consequently, $\lambda_{3}$ is the most accurately defined axis; it lies

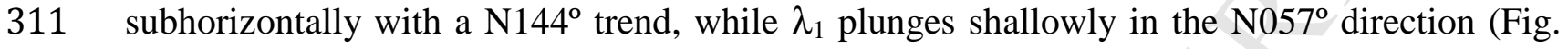

312 7d). Figure 8 illustrates the results of fault analysis on the scale of a pit $\sim 200 \mathrm{~m}$ wide within

313 the main area of investigation (Pit 208) and on an isolated site located $2 \mathrm{~km}$ further northwest

314 (Bilboquet, see Figure 2a for location). Fault slip analysis on these sites yields results that fit

315 closely with those deduced from the bulk dataset.

Further southwest and at lower elevation with respect to the open pits, the mine access

road provides a large outcrop near the transition between the upper and intermediate structural

levels (Roadsite '620 m' in Figure 2a). It shows fault planes with slickenfibers as well as shear zones a few centimeters thick (Fig. 5f), both involving polygonal serpentine. Fault slip analysis yields an ellipsoid in the flattening field $(\mathrm{R}=0.66)$, with $\lambda_{3}$ shallowly plunging southward $\left(27^{\circ}\right)$ along a N006 $6^{\circ}$ trend (Fig. 9). This is broadly consistent with the synpolygonal serpentine strain field deduced from the open pits (Fig. $7 d$ ), though with a $\sim 40^{\circ}$ clockwise rotation in the direction of $\lambda_{3}$. This difference could reflect differential large-size block rotations post-dating the measured fault slip increments. However, in this area, dunitic interlayers retain the same ENE-WSW strike and $\sim 50^{\circ}$ southward dip as elsewhere in the Koniambo Massif (Maurizot et al., 2002), therefore this hypothesis is unlikely. Hence, the difference is more likely to reflect a modification of the strain field through space or time. 
laterally variable. The main part is similar to exposures of the Upper structural level, with a

331 dense network of serpentine-bearing fractures. The distinctive feature of the Intermediate structural level is that this rock mass is crosscut by low-dipping shear zones a few meters thick, characterized by a pervasive development of light green polygonal serpentine (Fig. 10a). Two such shear zones (SZ1 and SZ2) occur at high levels of the Intermediate structural 335 level (Fig. 2a). The NE-SW horizontal spacing between the two shear zones is $\sim 450 \mathrm{~m}$.

336 Continuous rock exposure along the mine access road enables to note that no similar shear zone exists between SZ1 and SZ2. Both SZ1 and SZ2 involve polygonal serpentine with a 338 closely spaced cleavage as well as magnesite (Fig. 10b,c,d,e). In the case of SZ1, striations 339 have not been observed. The direction of shearing is assumed to lie at right angle to the 340 intersection between the cleavage and shear planes located along the margins of the shear 341 zone (Fig. 10b,c), along a $\sim 234^{\circ}$ trend (Fig. 10f). In the case of SZ2, a major fault plane in

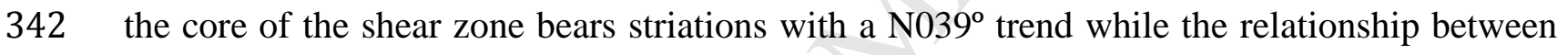
343 cleavage and shear bands suggests a $\sim \mathrm{N} 085^{\circ}$ trend for the direction of shearing (Fig. 10e,f). 344 Both shear zones have top-to-SW kinematics. SZ1 has the attitude of a reverse-slip shear zone 345 (Fig. 10a,b,c,f) while SZ2 combines reverse and dextral displacements (Fig. 10e,f).

At lower elevations, the mine access road crosscuts a prominent SW-dipping fault 347 zone involving a $\sim 30$ m-thick pinch of fine-grained sediments (Maurizot et al., 2002) (Fig. 348 11a). These sediments are originally part of either the 'Poya terrane' (Maurizot et al., 2002) 349 or, more likely, the 'Nepoui flysch' (D. Cluzel, personal communication, 2012). As a result, 350 they represent a fragment of the volcano-sedimentary series that immediately underlie the 351 Peridotite Nappe (Cluzel et al., 2001). Hence, the fault zone likely roots slightly beneath the 352 basal contact of the nappe, or along it if one takes into account the fact that sheets of 353 serpentinite are frequently mixed with substratum rocks around several klippes of the nappe 354 (e.g., Maurizot et al., 1985). Within the fault zone, the main fault superposes highly sheared serpentinites onto the sediments (Fig. 11a). Its orientation is $\mathrm{N} 146^{\circ}, 38^{\circ} \mathrm{SW}$ and it bears 
pronounced striations with a N072 ${ }^{\circ}$ trend (Fig. 11b). Along this contact and across a structural thickness of at least $75 \mathrm{~m}$ above it, shear sense criteria indicate a reverse-slip (top-to-ENE) displacement (Fig. 11c,d). This movement is consistent with the incorporation of rocks from the substratum into the fault zone, and with the probable offset of the roof of the serpentine sole across it (Fig. 2a,b). This top-to-ENE fault can be viewed as a conjugate shear with respect to the top-to-SW SZ1 and SZ2 shear zones.

\subsubsection{Lower structural level (the serpentine sole)}

The best exposures of the serpentine sole lie in the Vavouto peninsula (Figs. 2, 3, 12

and 13). Further east, the map contour of the basal contact of the nappe implies a culmination of this contact slightly northwest of the Tambounan Peak (Fig. 2a). As a result, the surface probably dips westward beneath the peninsula, with a slope of $\sim 6-7^{\circ}$ (Fig. 2b). The contact is exposed at the eastern margin of the peninsula, displaying $\sim \mathrm{E}-\mathrm{W}$-trending open folds on a $\sim 100 \mathrm{~m}$ scale (Fig. 3a).

The rocks along the sole are brecciated and/or foliated. Breccias are well developed along the VA1 section (Fig. 12a) and consist of clasts of serpentinized peridotite separated by serpentine joints (Fig. 4d). Many joints bear very fine striations (Fig. 4c). The striations have extremely variable orientations, which probably results from the complexity of clast displacements/rotations during brecciation. Major shear zones occur along the VA1 section (Fig. 2c), marked by a reduction in clast size (Figs. 12a and 13a). The shear zone boundaries

375 are dominantly diffuse, but locally change to sharp. The width of the main shear zones ranges 376 from $\sim 2$ to $\sim 10 \mathrm{~m}$. In the shear zones, the greater density of fault planes subparallel to their 377 walls tends to produce elongate clasts that locally define a crude foliation (e.g., in the upper 378 part of Figure 13b). In the core of some shear zones, the planar fabric is more pronounced and 379 locally oblique to the shear zone walls. In cases where this oblique fabric had the appearance 380 of a closely spaced cleavage, it helped to assess the kinematics of the shear zone. In most 
cases, however, it is difficult to decide whether the fabric could alternatively represent a dense pattern of Riedel shears, hence implying the opposite sense of shear compared to that deduced from an oblique cleavage. As a result, the kinematics of individual shear zones and shear planes along the VA1 section has essentially been deduced from their effect (offset and drag folding) on pre-existing markers (Figs. 12b and 13b).

The largest part of the VA2 section consists of serpentinites with a pronounced planar fabric (Figs. 3a and 12c). On a $10 \mathrm{~cm}$ scale, this fabric is underlined by a disjunctive anastomosing cleavage (Fig. 13c). When present, clasts are isolated, hence the rock retains a matrix-supported texture (Fig. 12d). Generally, the clasts have an elongate and subangular to rounded shape with a consistent orientation throughout the rock (Fig. 12d). As a result, the rock has the typical appearance of a mylonite. Early compositional layering has been transposed into parallelism with the cleavage (Fig. 12c), attesting for very large strains. Under microscope, the fabric of the foliated serpentinites is irregularly distributed but locally pervasive (e.g., in the right part of Figure 13d). A component of ductile deformation is thus involved. The northern end of the VA2 section shows that the foliated serpentinites occur immediately above the basal contact of the nappe (Fig. 3a). The southern end of the section shows that they underlie the part of the sole dominated by breccias through a relatively sharp transition zone (Fig. 3b). Hence, the foliated serpentinites form a distinct layer of most intensely deformed rocks at the base of the serpentine sole, with a thickness of at least $20 \mathrm{~m}$.

As illustrated by the third reference sample in Section 4.1 (Fig. 4c,d), our observations indicate that the major shear zones along the VA1 section involve pale green polygonal serpentine as the main syn-kinematic mineral phase (Figs. 12a and 13a,b). This also applies to the layer of foliated serpentinites of the VA2 section (Figs. 12c,d and 13c). Magnesite also occurs within this layer and along the VA1 section, in the form of irregularly distributed veins and local stockworks (Figs. 2c, 12c and 13a). Magnesite occurs in close association with 
polygonal serpentine (Figs. 12c,d and 13a,b,c). Evidence of the syn-kinematic nature of the

407 magnesite veins is shown in Figure 13 (see also Quesnel et al., 2013). In the macroscopic examples $\mathrm{b}$ and $\mathrm{c}$, the veins are offset by local shear planes that contribute to the bulk shearing deformation. In addition to the vein infilling habitus, elongate clusters of partly coalescent millimetric to centimetric nodules of magnesite are occasionally found. Figure 13d shows part of a pluricentimetric nodule under microscope. Its right margin is irregular, made up of submillimetric nodules of cryptocrystalline magnesite. This geometry, which suggests an unconstrained growth of magnesite, could be taken as an indication that magnesite has

414 formed in the absence of contemporaneous deformation, after the development of the shear 415 fabric visible in the host serpentinite. However, the upper margin of the nodule is straight and 416 coincides with one of the shear bands related to this fabric. The relations between the nodule 417 and the shear band, highlighted in the enlargement, are clearly more in line with the shear band post-dating the nodule than with the opposite. Overall, the relations seen in Figure 13d are consistent with magnesite having grown during shearing.

The asymmetric distribution of shear zones along the VA1 (Fig. 2c) and VA2 (Fig. 12c) sections documents non coaxial deformation across the serpentine sole. The exposure surface being smooth along both sections, the orientation of the main shear zones is difficult to evaluate. Nevertheless, a dozen shear planes of significant size (several meters) have been measured along the VA1 section (Fig. 12e). Their mean orientation is $\mathrm{N} 141^{\circ}, 46^{\circ} \mathrm{SW}$. This suggests top-to-SW kinematics for the bulk shearing deformation. Top-to-SW shearing is consistent with the orientation of steep planar magnesite veins in between the shear zones 427 (mean value $\mathrm{N} 134^{\circ}, 62^{\circ} \mathrm{SW}$ ), interpreted as tension gashes (Quesnel et al., 2013), and with the 428 orientation of folds developed at the expense of magnesite veins within the shear zones (Fig. 429 12e). Top-to-SW shearing is also consistent with the apparent top-to-west vs. top-to-south 430 sense of shear observed along the $\sim \mathrm{W}$-E-trending VA1 vs. $\sim \mathrm{N}-\mathrm{S}$-trending VA2 section, 431 respectively. The orientation of the ellipsoid delineated by the large ovoid clast in the upper 
432 left corner of Figure $3 \mathrm{a}$ also fits with this interpretation. Along the VA1 section, the major

433 shear zones with an apparent top-to-west sense of shear have a mean apparent dip of $24.5^{\circ}$

434 (Fig. 2c). Assuming that the mean strike of these shear zones is N141 ${ }^{\circ}$ (i.e. the same as for the

435 meter-scale shear planes) and taking into account the N082 ${ }^{\circ}$ strike of the VA1 section, the

436 mean true dip of the major shear zones can be estimated at $\sim 28^{\circ}$. Taking into account the

437 likely $\sim 6-7^{\circ}$ westward slope of the basal contact of the nappe beneath the Vavouto peninsula

438 (Fig. 2b), the obliquity of the main shear zones with respect to the boundaries of the

439 serpentine sole is probably around $22^{\circ}$. This obliquity is consistent with an interpretation of

440 the shear zones as large C'-type shear bands (Berthé et al., 1979; Passchier and Trouw, 1996)

441 developed during strong tangential shear across the serpentine sole. Smaller equivalent 442 structures are visible in Figures $12 \mathrm{c}, 13 \mathrm{~b}$ and 13c. Finally, it should be noted that flat-lying 443 antithetic shear planes also occur in the eastern part of the VA1 section (Figs. 2c and 12b). In 444 Figure 12b, they crosscut the main southwest-dipping shear fabric, however their relationship 445 with one of the major shear zones suggests that they may have developed contemporaneously.

\section{5. Discussion}

447 5.1. The distribution of deformation in the Koniambo Massif

448 Figure 14 summarizes the results of our structural analysis while Figure 15 illustrates the 449 possible relationships between the three structural levels identified in the Koniambo Massif.

The Upper structural level is characterized by a very dense network of fractures filled

451 with one or several types of serpentine. Antigorite and polygonal serpentine commonly form 452 slickenfibers along fault planes, which we used for analyzing fault slip data. The bulk 453 deformation associated with antigorite-bearing faults is characterized by a highly 454 constrictional ellipsoid with $\lambda_{1}$ lying horizontally along a N102 $2^{\circ}$ trend. The bulk deformation 455 associated with polygonal serpentine-bearing faults is characterized by an ellipsoid in the 456 flattening field with $\lambda_{3}$ lying subhorizontally along a N144 ${ }^{\circ}$ trend. 
The Lower structural level coincides with the serpentine sole. As a rule in New

458 Caledonia (e.g., Avias, 1967; Leguéré, 1976; Cluzel et al., 2012), the serpentine sole of the

459 Koniambo Massif is intensely deformed. Breccias dominate while foliated serpentinites,

460 interpreted as mylonitic rocks, form a distinct basal layer at least $20 \mathrm{~m}$ thick. The sole has

461 experienced pervasive non-coaxial deformation with a top-to-SW sense of shear. Polygonal

462 serpentine and magnesite are syn-kinematic phases with respect to this deformation. Along

463 the VA1 section, major low-dipping shear zones are distributed with a $100 \mathrm{~m}$ lengthscale

464 (Fig. 2c). As described in Section 4.3.3, their mean obliquity with respect to the basal contact

465 of the nappe is estimated at $\sim 22^{\circ}$. We interpret these shear zones as C'-type shear bands

466 developed within a thick zone of strong tangential shear that coincides with the serpentine

467 sole (Figs. 14 and 15; see also Lahondère et al., 2012, their figure 115). In line with this

468 interpretation, no equivalent shear zone is observed above the serpentine sole.

The Intermediate structural level is characterized by the presence of several metersthick reverse-slip shear zones. Top-to-SW shear zones are synthetic to pervasive shearing 471 along the serpentine sole and, likewise, involve polygonal serpentine and magnesite as synkinematic mineral phases. Therefore, although we had no opportunity to observe this contact in the field, we suppose that the shear zones root along the roof of the serpentine sole, the

474 whole sole acting as a décollement (Fig. 14 and, in Figure 15, geometric relationship 'r1'). In 475 Figure 15, the roof of the sole is schematically shown as a distinct fault; in reality, it is more 476 likely to coincide with a zone across which the intensity of brecciation progressively 477 diminishes. In addition, some shear zones may root at deeper level (Fig. 15, relationship 'r2'), 478 for instance along the relatively sharp contact between the foliated serpentinites and the 479 overlying serpentinite breccias (Fig. 3b) and/or along the basal contact of the nappe. This 480 possibility is suggested by the presence of a relatively large top-to-SW reverse-slip shear zone 481 at the northern end of the VA2 section (Fig. 3a) and by the characteristics of the fault zone of 
The NE-SW horizontal spacing between two consecutive top-to-SW shear zones, SZ1

and SZ2, is $\sim 450 \mathrm{~m}$. This is slightly less than the thickness of the Upper structural level in the Koniambo Massif (Fig. 2b) and much less than the thickness of the Peridotite Nappe in the

Massif du Sud ( $\geq 1.5 \mathrm{~km})$. This narrow spacing suggests that at least some of the shear zones do not cross the nappe up to the surface but remain confined to the Intermediate structural level. In fact, although rock exposures are abundant in the open pits of the top of the Koniambo Massif, we have not observed any such shear zone in the Upper structural level. Based on this indirect evidence, it is here suggested that the shear zones may connect to another flat-lying décollement located along the roof of the Intermediate structural level (Fig. 15 , relationship ' $r 3$ '). Like for the roof of the sole, this décollement might not coincide with a distinct fault but with a zone across which the reverse-slip displacement of the shear zones could be absorbed through diffuse faulting. In addition, a few major shear zones may ramp up to the surface (Fig. 15, relationship ' $r 4$ '). No such shear zone is observed in the Koniambo Massif but one likely exists in the northern part of the nearby Kopéto-Boulinda Massif (see Figure 1 for location). It is highlighted by a north-dipping serpentinite sheet about $200 \mathrm{~m}$ thick that emanates from the serpentine sole of this massif, at elevations around $200 \mathrm{~m}$, and 499 climbs among the peridotites up to an elevation of at least $500 \mathrm{~m}$ (Maurizot et al., 1985, their 500 figure 4; Maurizot, 2007). The precise geometry and the kinematics of this probable shear 501 zone remain to be documented.

Finally, top-to-NE shear zones also exist in the Koniambo Massif, as subsidiary structures in the serpentine sole and as conjugate shears with respect to the top-to-SW shear

504 zones in the Intermediate structural level. Because it roots along or slightly beneath the base 505 of the serpentine sole and likely offsets its roof (Fig. 2b), the reverse fault zone of Figure 11 is 506 probably a relatively late feature with respect to pervasive top-to-SW shearing along the sole. 507 The shear zone labelled 'r2', in Figure 15, would be an equivalent synthetic shear zone. 
5.2. The temporal evolution of deformation

509 Our analysis documents major variations in the orientation of the principal strain axes. At

510 least part of these variations reflect a temporal evolution (Fig. 14). This is the case within the

511 Upper structural level, where fault slip data associated with antigorite and polygonal

512 serpentine were collected in the same restricted area but yielded two strikingly different strain

513 ellipsoids. Microstructural observations indicate that polygonal serpentine postdates antigorite

514 (see Sections 4.1 and 4.3.1), in agreement with the time sequence identified by Ulrich (2010)

515 in the serpentine sole of the Koniambo Massif. Hence, the Upper structural level keeps the

516 record of a temporal change from WNW-ESE horizontal stretching, during antigorite crystallization, to NW-SE horizontal shortening, during polygonal serpentine crystallization.

The origin of the other variations in orientation of the principal strain axes is more difficult to assess because they involve the same serpentine polymorph (polygonal serpentine) and occur across distinct levels of the nappe. Therefore, the change from NW-SE shortening in the Upper structural level to NE-SW shearing in the serpentine sole could reflect a spatial rather than a temporal evolution, i.e. vertical strain partitioning at a specific evolutionary stage of the nappe. The $\sim \mathrm{N}-\mathrm{S}$ direction of shortening recorded at an intermediate structural

524 height, on roadsite ' $620 \mathrm{~m}$ ', may support this view. Nevertheless, the observed changes in shortening direction are more likely to reflect a temporal evolution. A first reason is that it seems difficult to conceive a tectonic setting in which the nappe would undergo horizontal

527 shortening at right angle to its direction of displacement (assuming the latter is given by the 528 direction of shear along the basal décollement). A second reason is the fact that, in the

529 Intermediate structural level, the main shear zones, which accommodate NE-SW shortening, crosscut rocks with the same dense network of fractures as in the Upper structural level (Fig.

531 10a). This relation suggests that the event having produced NE-SW shortening in the 532 Intermediate structural level (and top-to-SW shearing in the sole) is younger than the fracture 
sets of the Upper structural level.

Thus, we suspect that both the syn-antigorite and the syn-polygonal serpentine fault

sets identifed in the Upper structural level are older than the top-to-SW shear deformation

536 observed in the serpentine sole. This contrasts with the opinion of Leguéré (1976) who supposed that the various sets of fractures he identified in the main mass of the nappe are all younger than the deformation recorded by the sole. According to Leguéré (1976), these fracture sets provide evidence for a three-step temporal evolution involving an episode of

ENE-WSW compression, then an episode of NNW-SSE compression, then an episode of

NNW-SSE extension. This scenario applies to the Kopéto-Boulinda and Koniambo Massifs, but the same events and the same chronology, with some variations in the orientation of the strain axes, are given by Leguéré (1976) for the other klippes of the Peridotite Nappe he

544 examined, spread over the Grande Terre. The episode of NNW-SSE compression, of fairly 545 constant orientation across the Grande Terre (Leguéré, 1976), correlates well with the syn546 polygonal serpentine event we identified in the Upper structural level of the Koniambo 547 Massif. The episode of NNW-SSE extension, which is more variable in orientation on the 548 scale of the Grande Terre (extension is locally WNW-ESE to W-E, cf. Leguéré, 1976), may 549 correlate with the syn-antigorite event we identified. Finally, the episode of ENE-WSW 550 compression, locally modified to a NE-SW compression (Leguéré, 1976), correlates with the 551 syn-polygonal serpentine \pm magnesite event we identified in the Intermediate structural level 552 and the serpentine sole. If so, however, the chronology of events proposed by Leguéré (1976) 553 differs strikingly from ours: his first event is our last one, and his last event is our first one. 554 We ignore the reasons for this disagreement, but note that Leguéré (1976) did not provide 555 details on the arguments he used for establishing his chronology. Our chronology is 556 essentially based on the identification of a sequence of minerals associated with deformation, 557 from antigorite to polygonal serpentine \pm magnesite. This sequence is consistent with a 558 progressive lowering in temperature conditions (Ulrich, 2010), which may reflect a 

nappe (Fig. 15). As a possible explanation for our disagreement with Leguéré (1976), we might have failed to identify one or several late episodes of normal faulting that are reported from the sedimentary series surrounding the klippes of the Peridotite Nappe (Lagabrielle et al., 2005; Chardon and Chevillotte, 2006).

\subsection{Relationships between deformation and serpentinization}

The three structural levels identified in the Koniambo Massif show strikingly different styles of deformation. These levels correlate fairly well with the subhorizontal lithological layering of the massif defined by Maurizot et al. (2002), which refers to variations in the intensity of serpentinization. Hence, it is tempting to consider that the intensity of serpentinization played a major role in the way deformation has been distributed across the Peridotite Nappe. As implicitly considered in several studies (e.g., Avias, 1967; Cluzel et al., 2001), the massive serpentinites of the sole might represent a layer of soft rocks having led to the individualization of a major décollement at the base of the nappe.

The Upper structural level displays a dense network of serpentine-bearing fractures, many of which have been activated as faults. Nevertheless, the bulk deformation associated with these faults is probably limited, as suggested by the fairly constant orientation of dunitic interlayers all across the Upper structural level (Maurizot et al., 2002). Moreover, as discussed in Section 5.2, the deformation recorded by the serpentine sole and the shear zones of the Intermediate structural level is likely younger than most fault sets of the Upper structural level. This supports the picture of an almost rigid Upper structural level by the time shearing was accumulating along the sole (cf. the strain-depth diagram in Figure 15). Could this behaviour relate to a least degree of bulk serpentinization in the Upper structural level?

Unlike in some parts of the Massif du Sud (e.g., Orloff, 1968), pristine peridotites are virtually absent from the Koniambo Massif. The least serpentinized rocks are found in the 
584 highest $\sim 200 \mathrm{~m}$ of the massif. In the field, they are identified as they seem to retain a

585 granoblastic texture, yet their dark green colour is symptomatic of a significant serpentine

586 content. Under microscope, these samples show 'mesh' textures resulting from a partial

587 replacement of olivine by lizardite (Fig. 6b). Serpentine mesh textures are essentially

588 pseudomorphic, therefore peridotites with these textures usually preserve their pre-

589 serpentinization fabrics (e.g., Wicks and Whittaker, 1977; Rouméjon and Cannat, 2014),

590 which also applies in that case (Fig. 6b; for other examples from the Koniambo Massif, see

591 Lahondère et al., 2012, their figures 301 to 304 and 309 to 312). This suggests that the Upper

592 structural level behaved almost rigidly ever since the early development of lizardite.

The mesh texture in Figure $6 \mathrm{~b}$ is classical (see also the examples of Lahondère et al.,

594 2012) in the sense that lizardite forms connected 'mesh rims' surrounding isolated olivine

595 'mesh cores' (e.g., Rouméjon and Cannat, 2014). This is a key observation because 596 theoretical considerations (e.g., Handy et al., 1999) as well as experimental results (Escartín et 597 al., 2001) indicate that, with such a texture, the peridotite should be nearly as weak as pure 598 serpentinite. The rock in Figure $6 \mathrm{~b}$ contains $~ 25 \%$ serpentine (estimated from image analysis) 599 whereas experimental evidence suggests that a $\sim 10-15 \%$ serpentine content is enough for 600 achieving the largest part of the strength drop with respect to the strength of a pure peridotite 601 (Escartín et al., 2001). Therefore, it seems that the highly uneven vertical distribution of syn 602 to post-serpentinization deformation across the height of the Koniambo Massif does not relate 603 to a parallel gradient in rock strength: within the range of observed variations in the degree of 604 serpentinization, all the rocks should have approximately the same strength (cf. Escartín et al., 605 2001).

606 5.4. What promoted strain localization at lower levels of the nappe?

607 The above discussion has shown that the degree of serpentinization is probably not the factor 608 which led deformation to localize along the sole of the nappe. A simple alternative may be 
considered where the gradient in rock strength is not located within the Peridotite Nappe but

610 arises from its juxtaposition against rocks of the substratum. In the Koniambo Massif, as for

611 the other klippes of the northwestern coast, this substratum is essentially composed of basalts

612 and dolerites (e.g., Guillon, 1975; Paris, 1981; Cluzel et al., 2001) (Fig. 3a). Such rocks are

613 clearly stronger than serpentinites (e.g., Ildefonse et al., 2007) and, following Escartín et al.

614 (2001), also stronger than slightly serpentinized peridotites. Hence, a strength profile may be

615 conceived where the whole Peridotite Nappe is weak, overlying a stronger substratum.

616 Deformation is then expected to concentrate in the part of the weak domain that is the closest

617 to the strong one, i.e. on the soft side of the main rheological boundary. This could account

618 for strain localization along the sole of the nappe.

Where basalts and dolerites underlie the Peridotite Nappe, the thickness of the

620 serpentine sole is great $(\sim 100-200 \mathrm{~m})$. This is the case in the Koniambo Massif and the other

621 klippes of the northwestern coast (e.g., Guillon, 1975). In contrast, smaller klippes located

622 further northeast, around the axis of the island, have a much thinner serpentine sole ( 10-20

$623 \mathrm{~m})$ and a substratum made of pervasively schistose fine-grained sediments with a low grade

624 metamorphic overprint. Typical examples are the Tchingou Massif (e.g., Maurizot et al.,

625 1985) and a series of kilometer-sized klippes around the Ougne summit (Maurizot et al.,

626 1989) (Fig. 1). Assuming that the thickness of the sole depends essentially on the intensity of

627 shearing, and assuming that the total amount of shear, linked to the displacement of the nappe,

628 is approximately constant over the area under consideration, this large difference in sole

629 thickness is consistent with the hypothesis that a lower vs. higher amount of strain is

630 accommodated by the nappe when its substratum is made of soft metasediments vs. strong

631 mafic rocks, respectively. This supports our proposal that strain localization along the base of

632 the nappe results from its juxtaposition against a stronger substratum. 
634 Three structural levels have been identified in the Koniambo Massif. The Upper structural

635 level, characterized by a dense network of fractures, keeps the record of at least two

636 deformation events, the first associated with antigorite (WNW-ESE extension), the second

637 with polygonal serpentine (NW-SE compression). The Lower structural level is represented 638 by the serpentine sole. It consists of massive tectonic breccias overlying a layer of mylonitic 639 serpentinites. The sole, which records pervasive tangential shear with top-to-SW kinematics, 640 can be interpreted as a décollement at the base of the nappe. The Intermediate structural level 641 exposes several meters-thick conjugate shear zones accommodating NE-SW shortening. Like 642 the sole, these shear zones involve polygonal serpentine and magnesite as the main syn643 kinematic mineral phases. The shear zones likely root into the basal décollement, either along 644 its roof or, occasionally, around its base.

Even the least altered peridotites, in the Upper structural level, contain so much serpentine that, according to theoretical and experimental work, they should be nearly as weak as pure serpentinite. Hence, no strong vertical gradient in strength due to variations in the degree of serpentinization is expected within the exposed part of the nappe. Strain localization along the serpentine sole probably results from the juxtaposition of the nappe, made of weak serpentinized peridotites, against stronger mafic rocks. In line with this view, the serpentine 651 sole is about ten times thinner when the substratum of the nappe is made of weak 652 metasediments, compared to what it is when the substratum is made of basalts and dolerites.

\section{Acknowledgments}

654 GeoRessources contribution has been supported by ANR-10-LABX-21-LABEX RESSOURCES 21. This work benefited from fruitful discussions with Marc Ulrich, Dominique Cluzel and Pierre Maurizot. We gratefully thank Sarah J. Titus and an anonymous reviewer for their constructive comments, and Toru Takeshita for editorial handling. 


\section{References}

660 Allmendinger, R.W., Cardozo, N., Fisher, D.M., 2012. Structural Geology Algorithms. 661 Cambridge University Press, Cambridge, p. 289.

662

663

664

665

666

667

668

669

670

671

672

673

674

675

676

677

678

679

680

681

682

683

684

685

Angelier, J., 1994. Fault slip analysis and paleostress reconstruction. In: Hancock, P.L. (Ed.), Continental Deformation. Pergamon Press, Oxford, pp. 53-100.

Angelier, J., Mechler, P., 1977. Sur une méthode graphique de recherche des contraintes principales également utilisable en tectonique et en sismologie: la méthode des dièdres droits. Bull. Soc. Géol. France 19, 1309-1318.

Auzende, A.L., Daniel, I., Reynard, B., Lemaire, C., Guyot, F., 2004. High-pressure behaviour of serpentine minerals: a Raman spectroscopic study. Phys. Chem. Miner. 31, 269-277.

Avias, J., 1967. Overthrust structure of the main ultrabasic New Caledonian massives. Tectonophysics 4, 531-541.

Bailey, W.R., Holdsworth, R.E., Swarbrick, R.E., 2000. Kinematic history of a reactivated oceanic suture: the Mamonia Complex Suture Zone, SW Cyprus. J. Geol. Soc. London $157,1107-1126$.

Berthé, D., Choukroune, P., Gapais, D., 1979. Orientations préférentielles du quartz et orthogneissification progressive en régime cisaillant: l'exemple du cisaillement sudarmoricain. Bull. Minéral. 102, 265-272.

Boudier, F., Ceuleneer, G., Nicolas, A., 1988. Shear zones, thrusts and related magmatism in the Oman ophiolite: initiation of thrusting on an oceanic ridge. Tectonophysics 151, 275296.

Butt, C.R.M., Cluzel, D., 2013. Nickel laterite ore deposits: weathered serpentinites. Elements 9, 123-128.

Carroué, J.P., 1972. Carte géologique de la Nouvelle-Calédonie à l'échelle 1/50000, feuille Pouembout. Bureau de Recherches Géologiques et Minières, map sheet and explanatory notes, p. 38 . 
Célérier, B., Etchecopar, A., Bergerat, F., Vergely, P., Arthaud, F., Laurent, P., 2012. Inferring stress from faulting: from early concepts to inverse methods. Tectonophysics 581, 206-219.

Chardon, D., Chevillotte, V., 2006. Morphotectonic evolution of the New Caledonia ridge (Pacific Southwest) from post-obduction tectonosedimentary record. Tectonophysics $420,473-491$.

Chevillotte, V., Chardon, D., Beauvais, A., Maurizot, P., Colin, F., 2006. Long-term tropical morphogenesis of New Caledonia (Southwest Pacific): importance of positive epeirogeny and climate change. Geomorphology 81, 361-375.

Cluzel, D., Aitchison, J.C., Picard, C., 2001. Tectonic accretion and underplating of mafic terranes in the Late Eocene intraoceanic fore-arc of New Caledonia (Southwest Pacific): geodynamic implications. Tectonophysics 340, 23-59.

Cluzel, D., Maurizot, P., Collot, J., Sevin, B., 2012. An outline of the geology of New Caledonia; from Permian-Mesozoic Southeast Gondwanaland active margin to Cenozoic obduction and supergene evolution. Episodes 35, 72-86.

Cluzel, D., Vigier, B., 2008. Syntectonic mobility of supergene nickel ores of New Caledonia (Southwest Pacific). Evidence from faulted regolith and garnierite veins. Resource Geol. $58,161-170$.

Coleman, R., 1971. Plate tectonic emplacement of upper mantle peridotites along continental edges. J. Geophys. Res. 76, 1212-1222.

Cook, C.A., Holdsworth, R.E., Styles, M.T., Pearce, J.A., 2000. Pre-emplacement structural history recorded by mantle peridotites: an example from the Lizard Complex, SW England. J. Geol. Soc. London 157, 1049-1064.

Coulton, A.J., Harper, G.D., O'Hanley, D.S., 1995. Oceanic versus emplacement age serpentinization in the Josephine ophiolite: implications for the nature of the Moho at intermediate and slow spreading ridges. J. Geophys. Res. 100, 22245-22260.

Dewey, J.F., Bird, J.M., 1971. Origin and emplacement of the ophiolite suite: Appalachian ophiolites in Newfoundland. J. Geophys. Res. 76, 3179-3206. 
Durney, D.W., Ramsay, J.G., 1973. Incremental strains measured by syntectonic crystal growths. In: de Jong, K.A., Scholten, R. (Eds.), Gravity and Tectonics. Wiley, New York, pp. 67-96.

Escartín, J., Hirth, G., Evans, B., 2001. Strength of slightly serpentinized peridotites: implications for the tectonics of oceanic lithosphere. Geology 29, 1023-1026.

Federico, L., Crispini, L., Vigo, A., Capponi G., 2014. Unravelling polyphase brittle tectonics through multi-software fault-slip analysis: the case of the Voltri Unit, Western Alps (Italy). J. Struct. Geol. 68, 175-193.

Gapais, D., Cobbold, P.R., Bourgeois, O., Rouby, D., de Urreiztieta, M., 2000. Tectonic significance of fault-slip data. J. Struct. Geol. 22, 881-888.

Guillon, J.H., 1975. Les massifs péridotitiques de Nouvelle-Calédonie. Mémoires de l'Office de la Recherche Scientifique et Technique Outre-Mer, Paris, vol. 76, p. 120.

Handy, M.R., Wissing, S.B., Streit, L.E., 1999. Frictional-viscous flow in mylonite with varied bimineralic composition and its effect on lithospheric strength. Tectonophysics 303, 175-191.

Hirth, G., Guillot, S., 2013. Rheology and tectonic significance of serpentinite. Elements 9, 107-113.

Ildefonse, B., Blackman, D.K., John, B.E., Ohara, Y., Miller, D.J., MacLeod, C.J., 2007. Oceanic core complexes and crustal accretion at slow-spreading ridges. Geology 35, 623626.

Lagabrielle, Y., Chauvet, A., Ulrich, M., Guillot, S., 2013. Passive obduction and gravitydriven emplacement of large ophiolitic sheets: the New Caledonia ophiolite (SW Pacific) as a case study? Bull. Soc. Géol. France 184, 545-556.

Lagabrielle, Y., Maurizot, P., Lafoy, Y., Cabioch, G., Pelletier, B., Régnier, M., Wabete, I., Calmant, S., 2005. Post-Eocene extensional tectonics in Southern New Caledonia (SW Pacific): insights from onshore fault analysis and offshore seismic data. Tectonophysics

741 Lahondère, D., Lesimple, S., Cagnard, F., Lahfid, A., Wille, G., Maurizot, P., 2012. Serpentinisation et fibrogenèse dans les massifs de péridotite de Nouvelle-Calédonie. 
Bureau de Recherches Géologiques et Minières, Public Report BRGM/RP-60192-FR, p. 458.

745

Lahondère, D., Maurizot, P., 2009. Typologie et protocole d'échantillonnage des occurrences naturelles d'amiante en Nouvelle-Calédonie. Bureau de Recherches Géologiques et Minières, Public Report BRGM/RP-57334-FR, p. 164.

Laó-Dávila, D.A., Anderson, T.H., 2009. Kinematic analysis of serpentinite structures and the manifestation of transpression in southwestern Puerto Rico. J. Struct. Geol. 31, 14721489.

Latham, M., 1977. On the geomorphology of northern and western New Caledonian ultramafic massifs. In: International Symposium on Geodynamics in South-West Pacific, 27 August-2 September 1976, Noumea, New Caledonia. Editions Technip, Paris, pp. 235-244.

Leguéré, J., 1976. Des corrélations entre la tectonique cassante et l'altération supergène des péridotites de Nouvelle-Calédonie. Ph.D. thesis, Université de Montpellier, France, p. 94.

Marrett, R., Allmendinger, R.W., 1990. Kinematic analysis of fault-slip data. J. Struct. Geol. 12, 973-986.

Maurizot, P., 2007. Cartographie d'aide à l'aménagement dans la zone Voh-KonéPouembout-Poya. Phase 1: Mise à jour de la carte géologique sur les communes de Koné et Pouembout et bilan des données existantes. Bureau de Recherches Géologiques et Minières, Public Report BRGM/RP-54898-FR, p. 76.

Maurizot P., Eberlé J.M., Habault C., Tessarolo C., 1989. Carte géologique de la NouvelleCalédonie à l'échelle 1/50000, feuille Pam-Ouégoa, $2^{\mathrm{e}}$ édition. Bureau de Recherches Géologiques et Minières, map sheet and explanatory notes, p. 81.

Maurizot, P., Feigner, D., Paris, J.P., 1985. Données nouvelles sur les «fils de serpentinite » de Nouvelle-Calédonie. Géol. France 1, 61-67.

Maurizot, P., Lafoy, Y., Poupée, M., 2002. Cartographie des formations superficielles et des aléas mouvements de terrain en Nouvelle-Calédonie, zone du Koniambo. Bureau de Recherches Géologiques et Minières, Public Report BRGM/RP51624-FR, p. 45. 
1/500000. Direction de l'Industrie, des Mines et de l'Energie - Service de Géologie de Nouvelle-Calédonie, Bureau de Recherches Géologiques et Minières.

774

775

776

777

778

779

780

781

782

783

784

785

786

787

788

789

790

791

792

793

794

795

Orloff, O., 1968. Etude géologique et géomorphologique des massifs d'ultrabasites compris entre Houailou et Canala (Nouvelle-Calédonie). Ph.D. thesis, Université de Montpellier, France, p. 189.

Paris, J.P., 1981. Géologie de la Nouvelle-Calédonie, un essai de synthèse. Mémoires du Bureau de Recherches Géologiques et Minières, vol. 113, p. 274.

Passchier, C.W., Trouw, R.A.J., 1996. Microtectonics. Springer, Berlin, p. 289.

Prinzhofer, A., Nicolas, A., Cassard, D., Moutte, J., Leblanc, M., Paris, J.P., Rabinovitch, M., 1980. Structures in the New Caledonia peridotites-gabbros: implications for oceanic mantle and crust. Tectonophysics $69,85-112$.

Quesnel, B., Gautier, P., Boulvais, P., Cathelineau, M., Maurizot, P., Cluzel, D., Ulrich, M., Guillot, S., Lesimple, S., Couteau, C., 2013. Syn-tectonic, meteoric water-derived carbonation of the New Caledonia peridotite nappe. Geology 41, 1063-1066.

Rouméjon, S., Cannat, M., 2014. Serpentinization of mantle-derived peridotites at mid-ocean ridges: mesh texture development in the context of tectonic exhumation. Geochem. Geophys. Geosyst. 15, 2354-2379.

Schemmann, K., Unruh, J.R., Moores, E.M., 2007. Kinematics of Franciscan Complex exhumation: new insights from the geology of Mount Diablo, California. Geol. Soc. Am. Bull. 120, 543-555.

Schwartz, S., Guillot, S., Reynard, B., Lafay, R., Debret, B., Nicollet, C., Lanari, P., Auzende, A.L., 2013. Pressure-temperature estimates of the lizardite/antigorite transition in high pressure serpentinites. Lithos 178, 197-210.

Spandler, C., Rubatto, D., Hermann, J., 2005. Late Cretaceous-Tertiary tectonics of the southwest Pacific: insights from $\mathrm{U}-\mathrm{Pb}$ sensitive, high-resolution ion microprobe (SHRIMP) dating of eclogite facies rocks from New Caledonia. Tectonics 24, TC3003.

Suhr, G., Cawood, P.A., 1993. Structural history of ophiolite obduction, Bay of Islands, Newfoundland. Geol. Soc. Am. Bull. 105, 399-410. 
800

801

802

803

804

805

806

807

808

809

810

811

812

813

814

815

816

817

818

819

820

821

822

823

824

825

826

Tikoff, B., Wojtal, S.F., 1999. Displacement control of geologic structures. J. Struct. Geol. 21, 959-967.

Titus, S.J., Fossen, H., Pedersen, R.B., Vigneresse, J.L., Tikoff, B., 2002. Pull-apart formation and strike-slip partitioning in an obliquely divergent setting, Leka Ophiolite, Norway. Tectonophysics 354, 101-119.

Titus, S.J., Maes, S.M., Benford, B., Ferré, E.C., Tikoff, B., 2011. Fabric development in the mantle section of a paleo-transform fault and its effect on ophiolite obduction, New Caledonia. Lithosphere 3, 221-244.

Trescases, J.J., 1975. L'évolution géochimique supergène des roches ultrabasiques en zone tropicale, formation des gisements nickélifères de Nouvelle-Calédonie. Mémoires de l'Office de la Recherche Scientifique et Technique Outre-Mer, Paris, vol. 78, p. 259.

Twiss, R.J., Moores, E.M., 1992. Structural Geology. W.H. Freeman and Company, New York, p. 532.

Twiss, R.J., Unruh, J.R., 1998. Analysis of fault slip inversions: do they constrain stress or strain rate? J. Geophys. Res. 103, 12205-12222.

Ulrich, M., 2010. Péridotites et serpentinites du complexe ophiolitique de la NouvelleCalédonie. Ph.D thesis, Université de Nouvelle-Calédonie et Université Joseph Fourier (Grenoble), France, p. 246.

Ulrich, M., Muñoz, M., Guillot, S., Cathelineau, M., Picard, C., Quesnel, B., Boulvais, P., Couteau, C., 2014. Dissolution-precipitation processes governing the carbonation and silicification of the serpentinite sole of the New Caledonia ophiolite. Contrib. Mineral. Petrol. 167, 952.

Ulrich, M., Picard, C., Guillot, S., Chauvel, C., Cluzel, D., Meffre, S., 2010. Multiple melting stages and refertilization as indicators for ridge to subduction formation: the New Caledonia ophiolite. Lithos 115, 223-236.

Wicks, F.J., Whittaker, E.J.W., 1977. Serpentine textures and serpentinization. Can. Mineral. $15,459-488$. 
828 Fig. 1. Simplified geological map of the Grande Terre, New Caledonia, showing the

829 exposures of ultramafic rocks. Most of these rocks are originally part of the Peridotite Nappe.

830 Adapted from Maurizot and Vendé-Leclerc (2009).

831 Fig. 2. a) Geological map of the central and southern parts of the Koniambo Massif, adapted 832 from Carroué (1972) and Maurizot et al. (2002). b) General cross-section of the Koniambo 833 Massif, located in (a). c) Report of the main fault zones along the VA1 section, in the 834 Vavouto peninsula.

835 Fig. 3. Two field views at the (a) northern and (b) southern ends of the VA2 section, in the 836 Vavouto peninsula (location in Figure 2a).

837 Fig. 4. Close views of the (a) first, (b) second and (c \& d) third reference samples discussed in 838 the text, and corresponding Raman spectra.

839 Fig. 5. Field views of serpentine-bearing (a to d) fault planes and (e \& f) shear zones in the 840 Upper structural level.

841 Fig. 6. a) Field view of an open pit with a dense network of fractures, typical from the Upper 842 structural level (location in Figure 2a). b) Photomicrograph of a sample representative of the 843 least serpentinized peridotites within the Koniambo Massif, from the Upper structural level, in 844 between the macroscopic fractures. The sample shows a typical 'mesh' texture composed of 845 lizardite (Liz) mesh rims surrounding olivine (Ol) and orthopyroxene (Opx) mesh cores.

846 Fig. 7. Lower hemisphere, equal-area projection showing the orientation of all measured (a) 847 syn-antigorite and (b) syn-polygonal serpentine faults at higher levels of the Koniambo 848 Massif (location in Figure 2a), and (c \& d) the result of the analysis of these fault slip data using the FaultKin software of Allmendinger et al. (2012). Kamb contours are shown for the axes of maximum stretching (in c) or maximum shortening (in d) with intervals in shades of

851 grey as depicted in the legend. The parameter $\mathrm{R}$ equates $\left(\varepsilon_{2}-\varepsilon_{3}\right) /\left(\varepsilon_{1}-\varepsilon_{3}\right)$ and describes the 
852 shape of the strain ellipsoid ( $\mathrm{R}$ is 0 for pure constriction, 0.5 for plane strain, and 1.0 for pure

853 flattening). Nmax is the number of faults compatible with the computed ellipsoid.

854 Fig. 8. Lower hemisphere, equal-area projection showing the orientation of faults at two 855 specific sites (location in Figure 2a), and the result of the analysis of these fault slip data.

856 Fig. 9. Lower hemisphere, equal-area projection showing the orientation of faults and minor 857 shear zones at roadsite ' $620 \mathrm{~m}$ ' (location in Figure 2a), and the result of the analysis of this 858 fault slip dataset. Kamb contours are shown for the axes of maximum shortening with 859 intervals in shades of grey as depicted in the legend.

860 Fig. 10. Field views of (a to d) SZ1 and (e) SZ2, two major low-dipping shear zones typical 861 from the Intermediate structural level (location in Figure 2a). Plg, polygonal serpentine; Mgs, 862 magnesite. f) Lower hemisphere, equal-area projection showing the orientation of structural 863 elements in the two shear zones (see the text).

864 Fig. 11. Field views of the reverse-slip fault zone with top-to-ENE kinematics shown in 865 Figure 2a,b.

866 Fig. 12. Field views of the serpentine sole in the Vavouto peninsula, along the (a \& b) VA1 867 and (c \& d) VA2 sections (location in Figure 2). Plg, polygonal serpentine; Mgs, magnesite. 868 e) Lower hemisphere, equal-area projection showing the orientation, along the VA1 section, 869 of large shear planes (shown as orange squares representing poles of planes), of planar 870 magnesite veins (shown as great circles) in between major shear zones, and of fold axes 871 (shown as black dots) of folded magnesite veins within the shear zones.

872 Fig. 13. Field views (a to c) and microphotograph (d) illustrating the relationships between 873 magnesite and deformation in the serpentine sole.

874 Fig. 14. Left, block-diagram depicting the style of deformation in the three structural levels 875 identified in the Koniambo Massif. For the Upper structural level, the drawing shows the 
876 deformation associated with polygonal serpentine, rather than with antigorite, because

877 polygonal serpentine is also the main mineral phase associated with major structures in the

878 other structural levels. Roadsite ' $620 \mathrm{~m}$ ' is shown at the top of the Intermediate structural

879 level to highlight its location at lower elevation in comparison to the main area of fault

880 measurements (see Figure 2a). Right, synthesis of the results of strain inversion as a function

881 of the structural level (vertically) and as a function of the main minerals associated with

882 deformation, which enable the determination of a sequence of events (horizontally).

883 Fig. 15. Schematic cross-section depicting the vertical distribution of deformation within the

884 Peridotite Nappe by the time top-to-SW shearing occurred along the serpentine sole. ' $r 1$ ' to

885 ' $r 4$ ' are geometric relationships discussed in the text. The thickness and the topography of the

886 nappe are poorly constrained and are likely to have changed during deformation. 


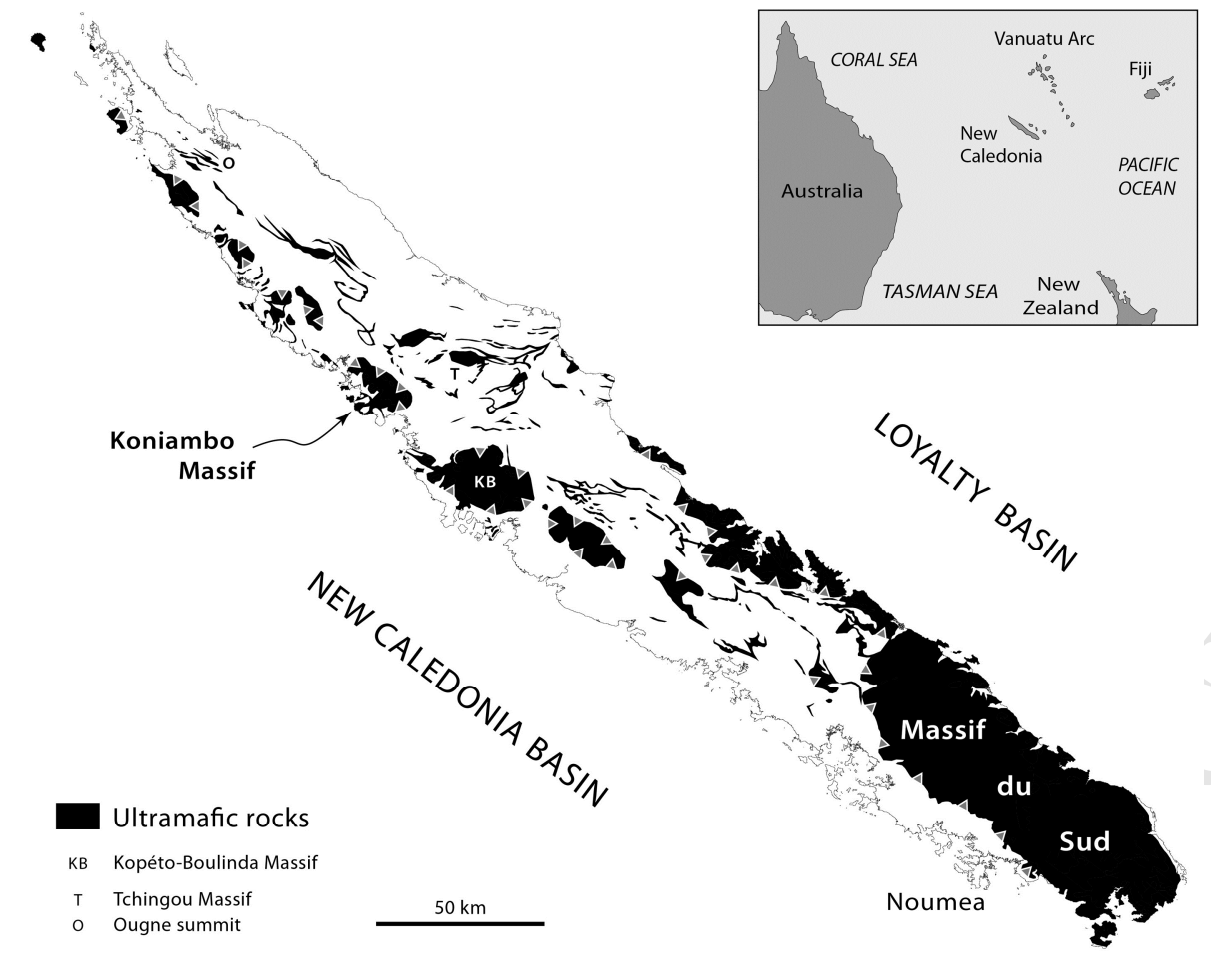



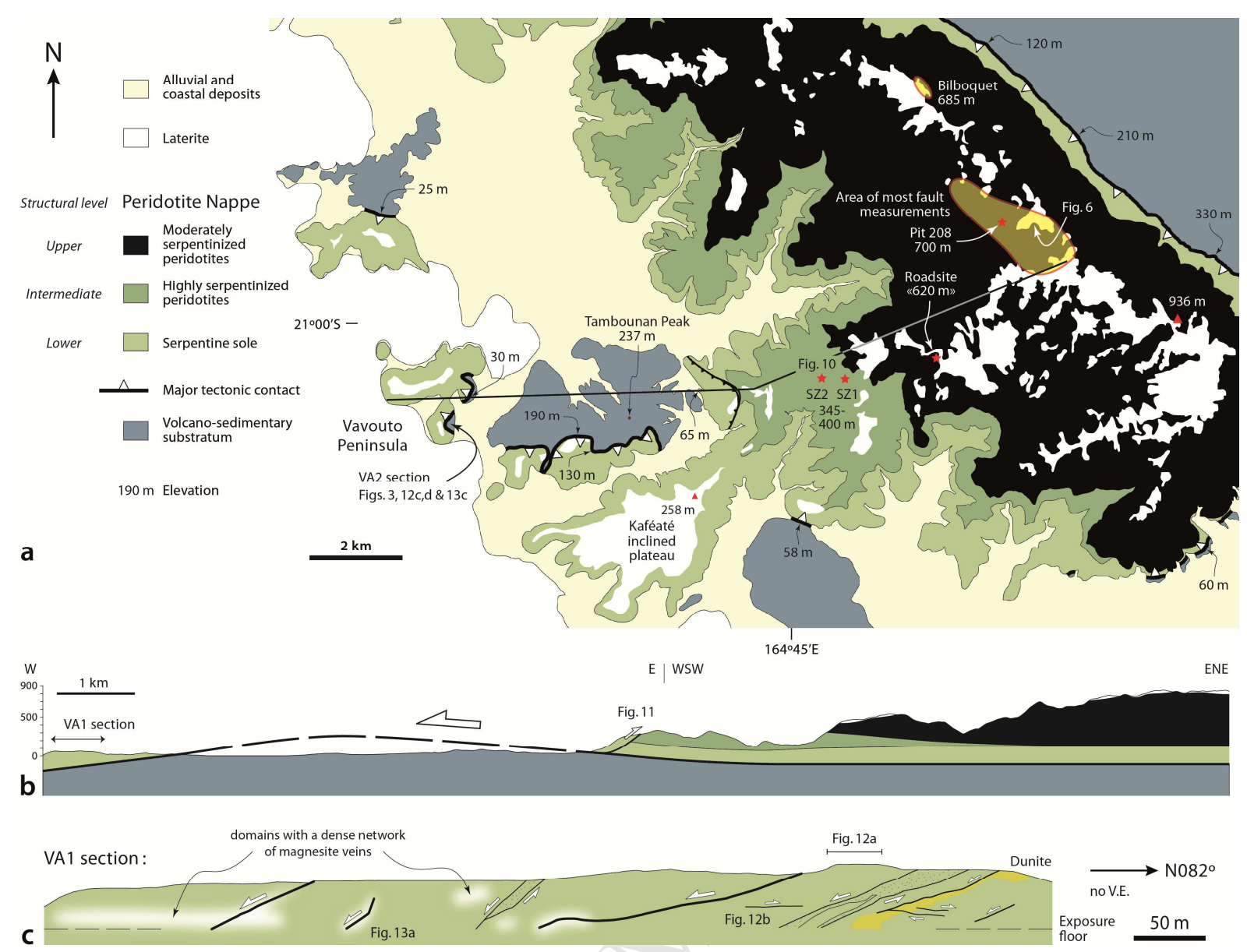

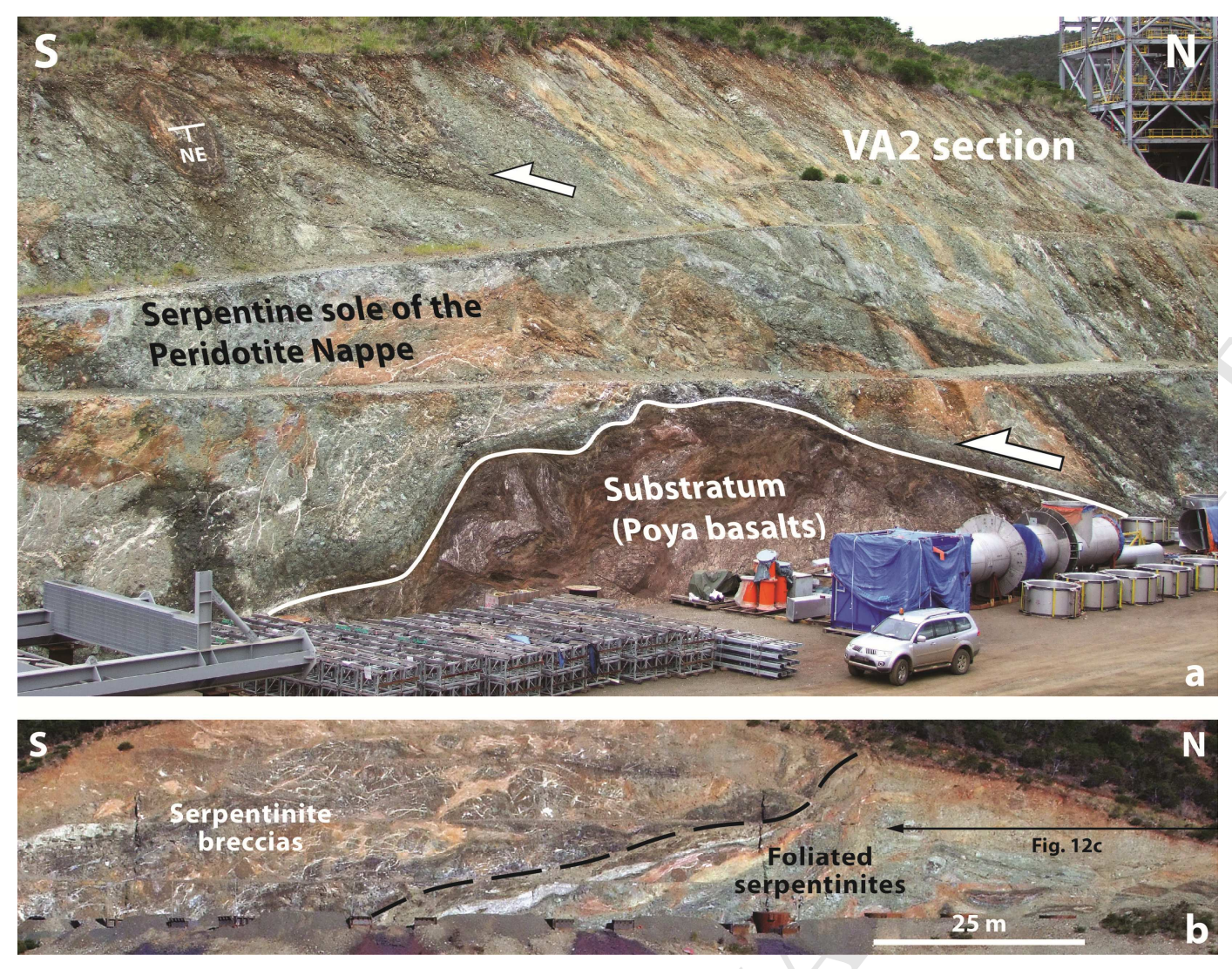


\section{ACCEPTED MANUSCRIPT}
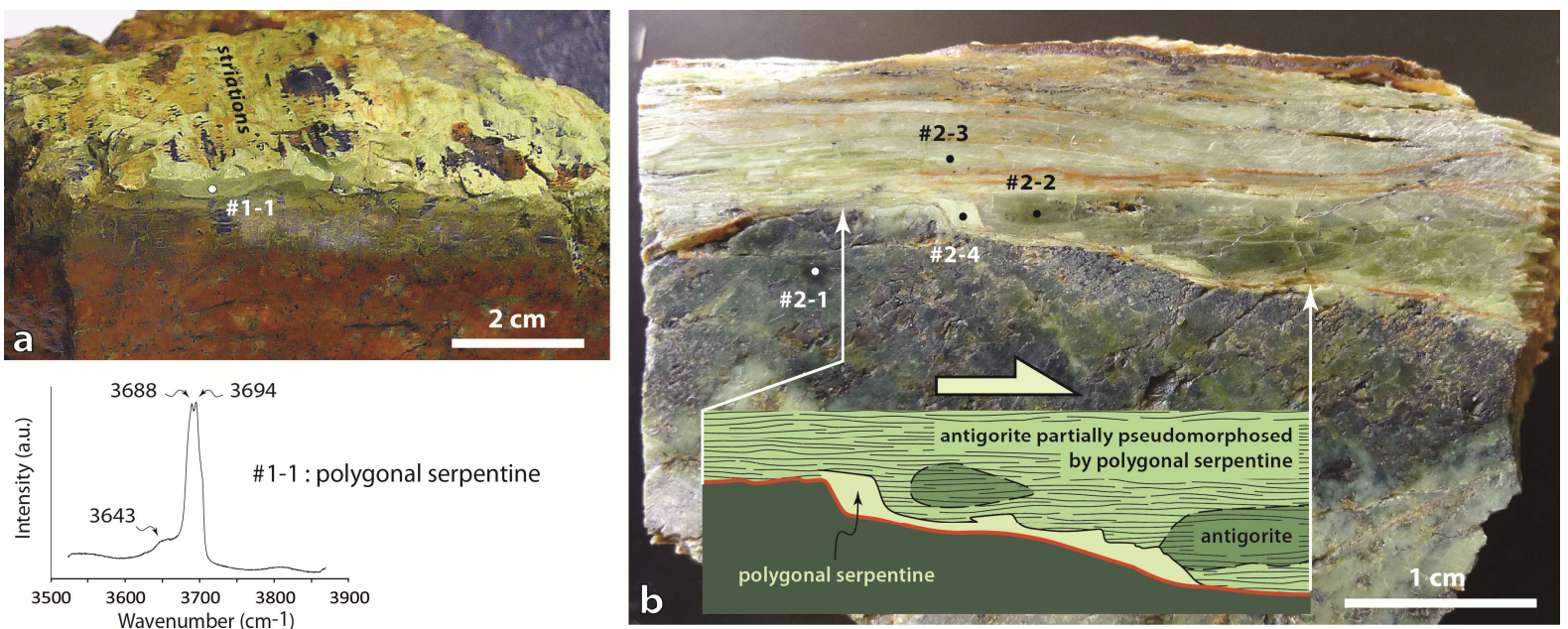

\#2-1 : polygonal serpentine

\#2-2 : antigorite

\#2-3 : antigorite
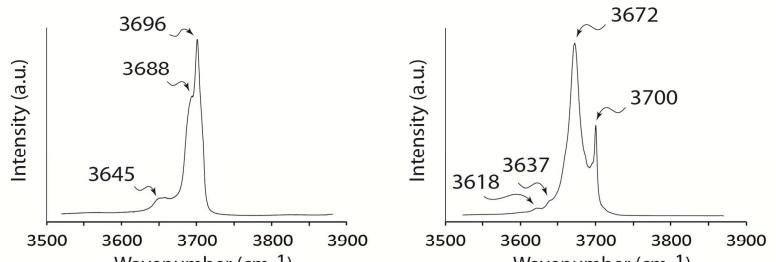

+ polygonal serp. ( \pm chrysotile?)

\#2-4 : polygonal serpentine

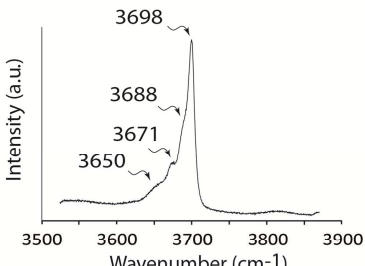
( \pm chrysotile?
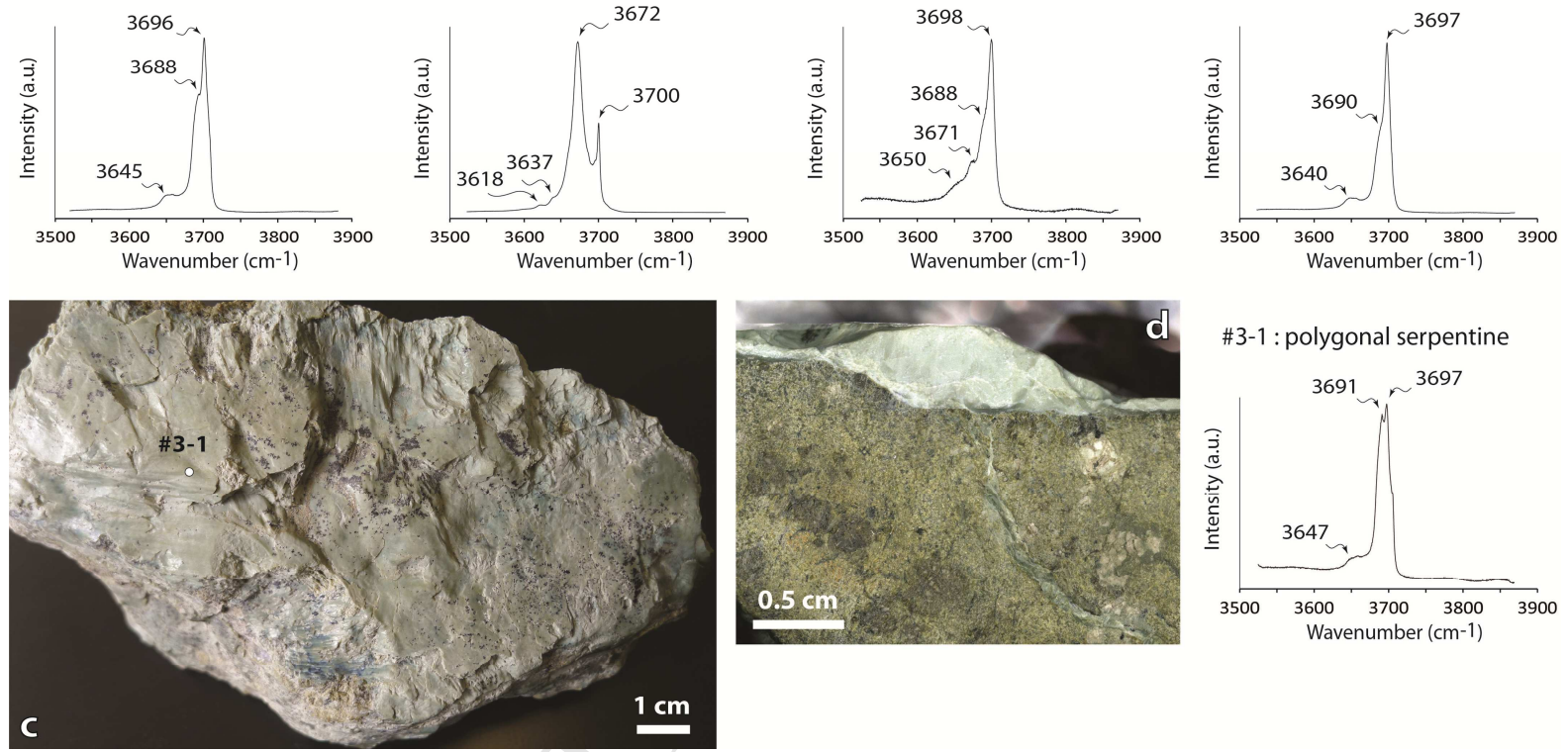

\#3-1 : polygonal serpentine

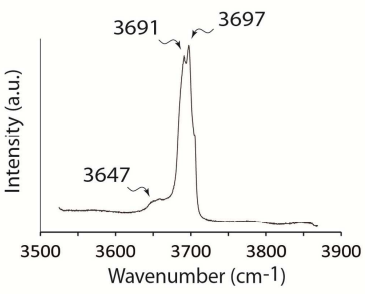



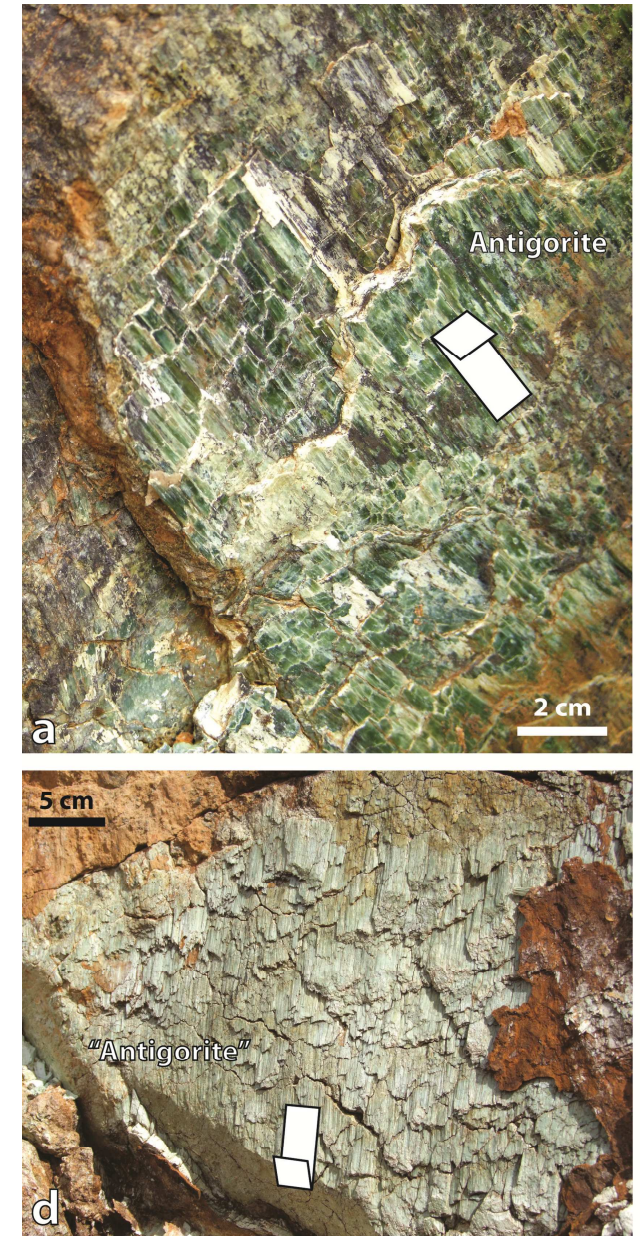
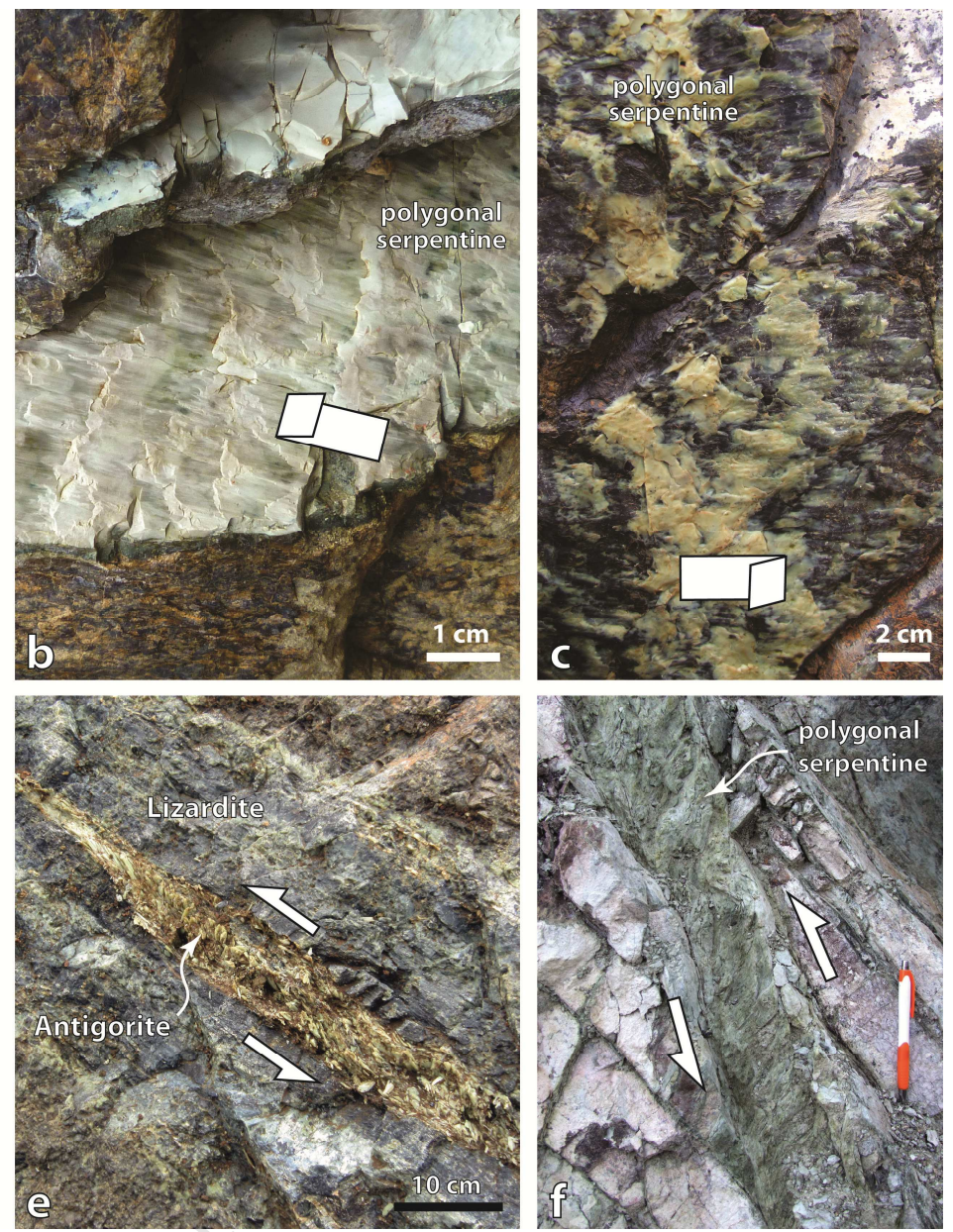

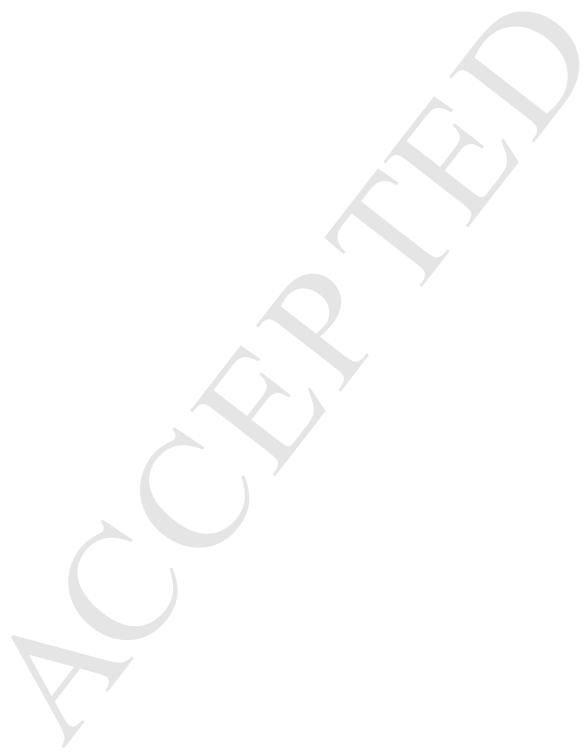




\section{ACCEPTED MANUSCRIPT}
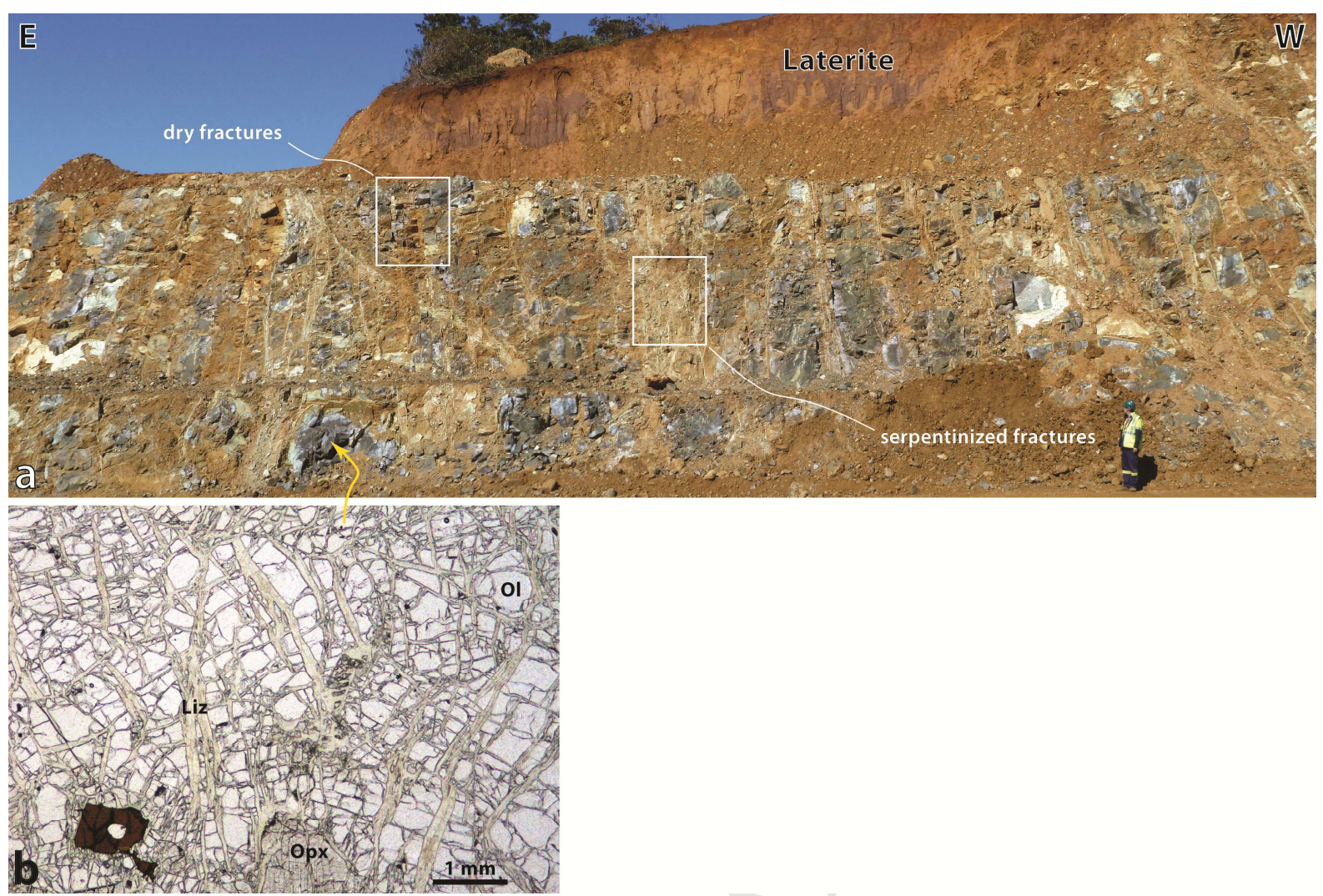


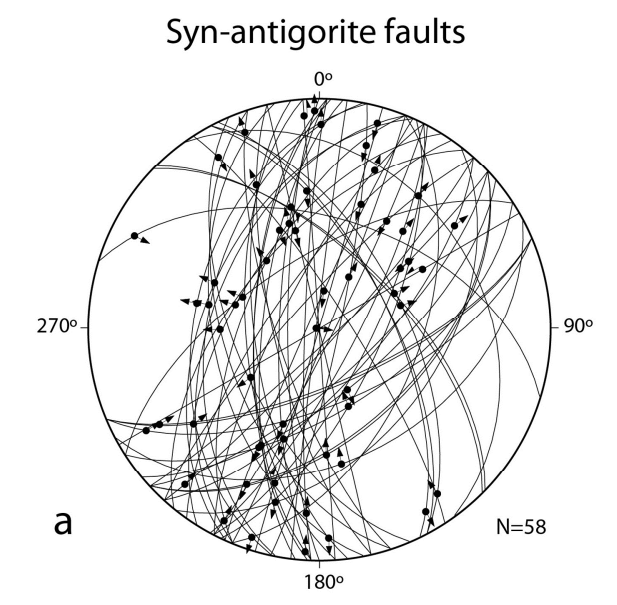

Syn-polygonal serp. faults
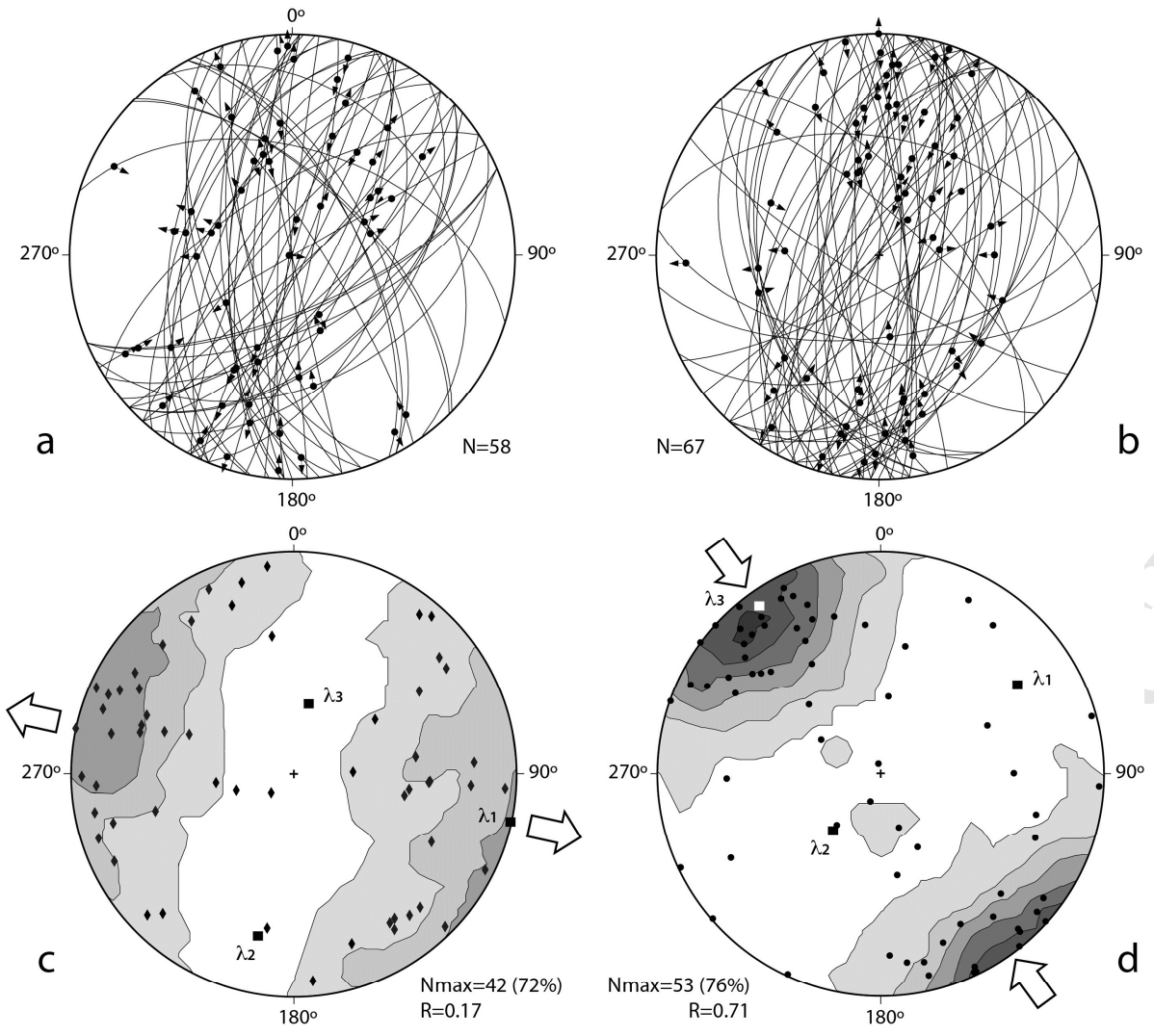
\begin{tabular}{l|l} 
- stretching axes & associated with individual faults \\
- shortening axes
\end{tabular}

$\begin{array}{llllllll}0 \sigma & 2 \sigma & 4 \sigma & 6 \sigma & 8 \sigma & 10 \sigma & 12 \sigma & 14 \sigma\end{array}$ 


\section{Syn-antigorite faults on Pit 208}

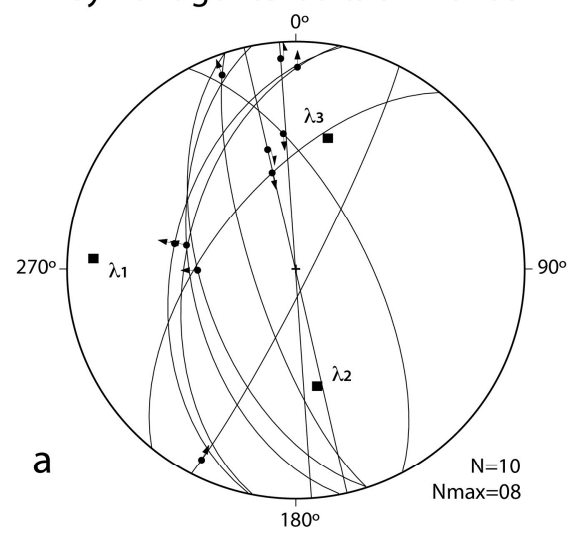

Syn-polygonal serp. faults on Pit 208

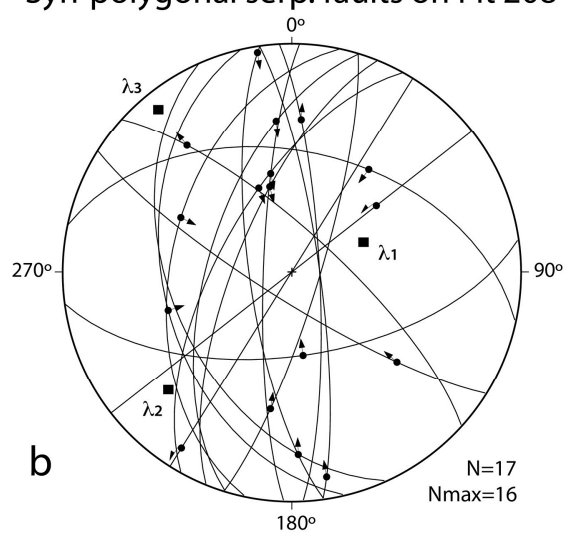

Syn-polygonal serp. faults on site «Bilboquet»

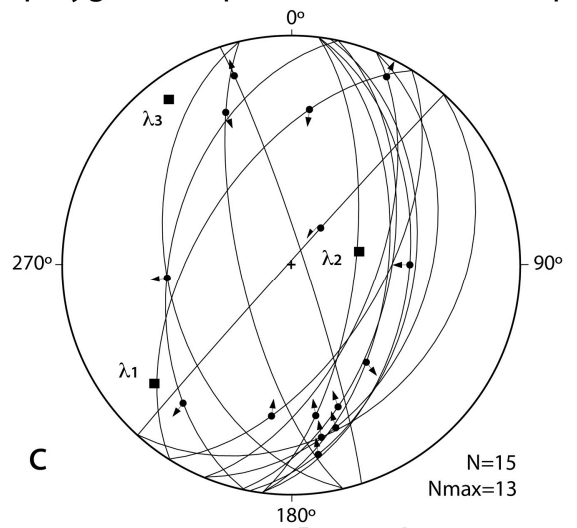


Syn-polygonal serpentine faults and minor shear zones, roadsite « $620 \mathrm{~m} »$
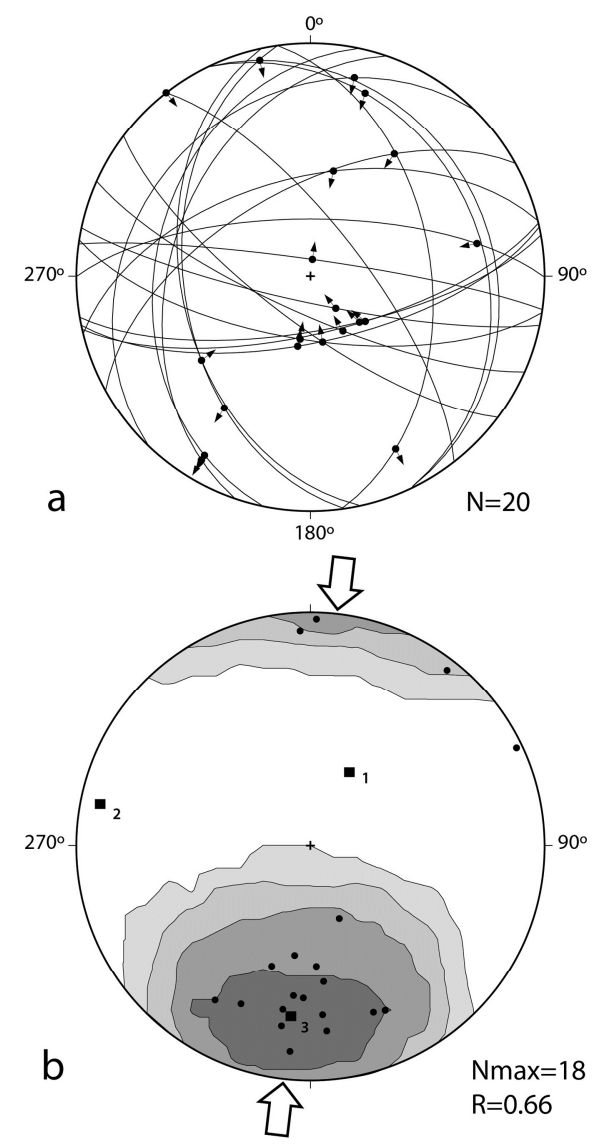

- shortening axes associated with individual faults $\begin{array}{lllllll}0 \sigma & 2 \sigma & 4 \sigma & 6 \sigma & 8 \sigma & 10 \sigma\end{array}$ 

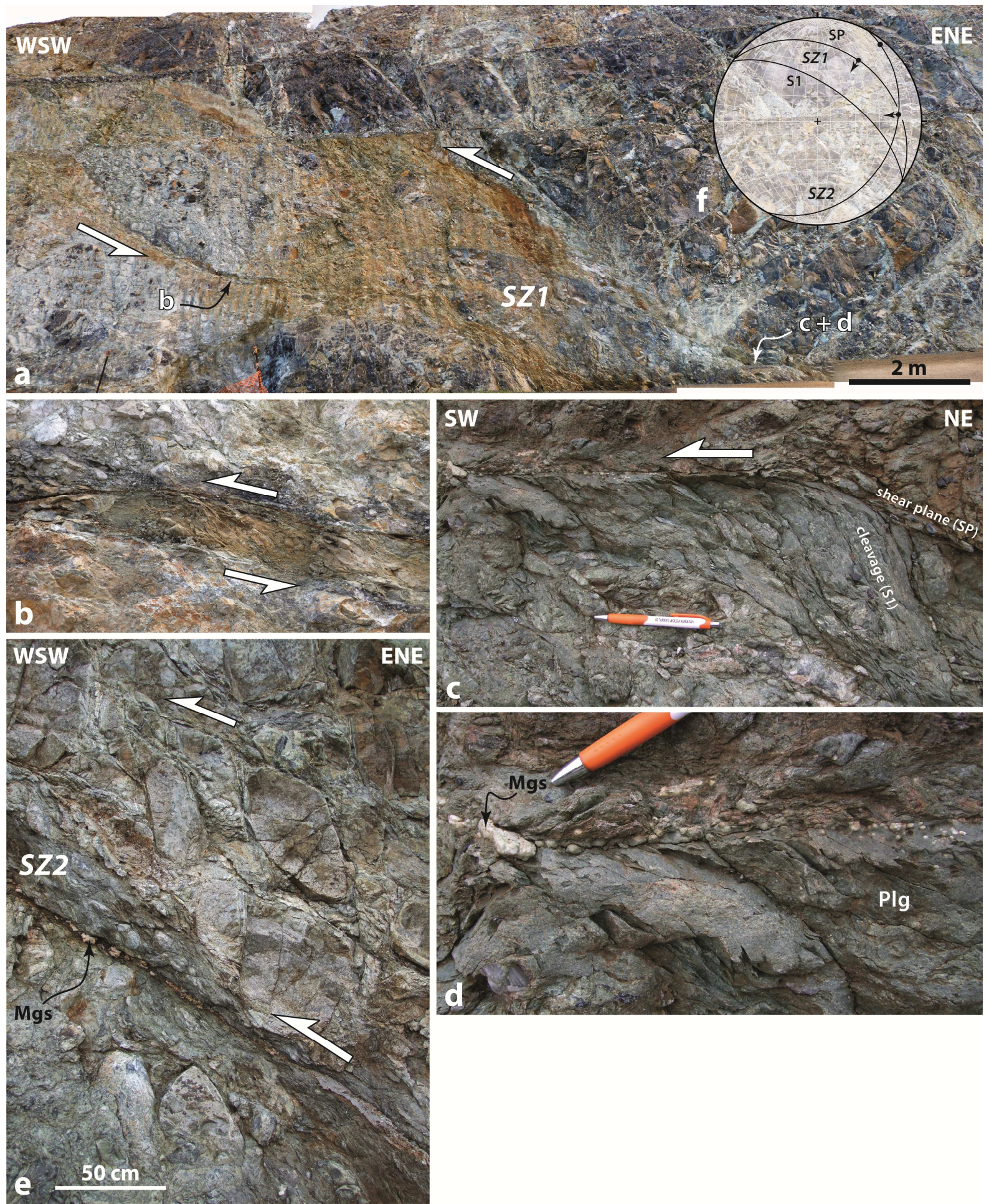


\section{ACCEPTED MANUSCRIPT}
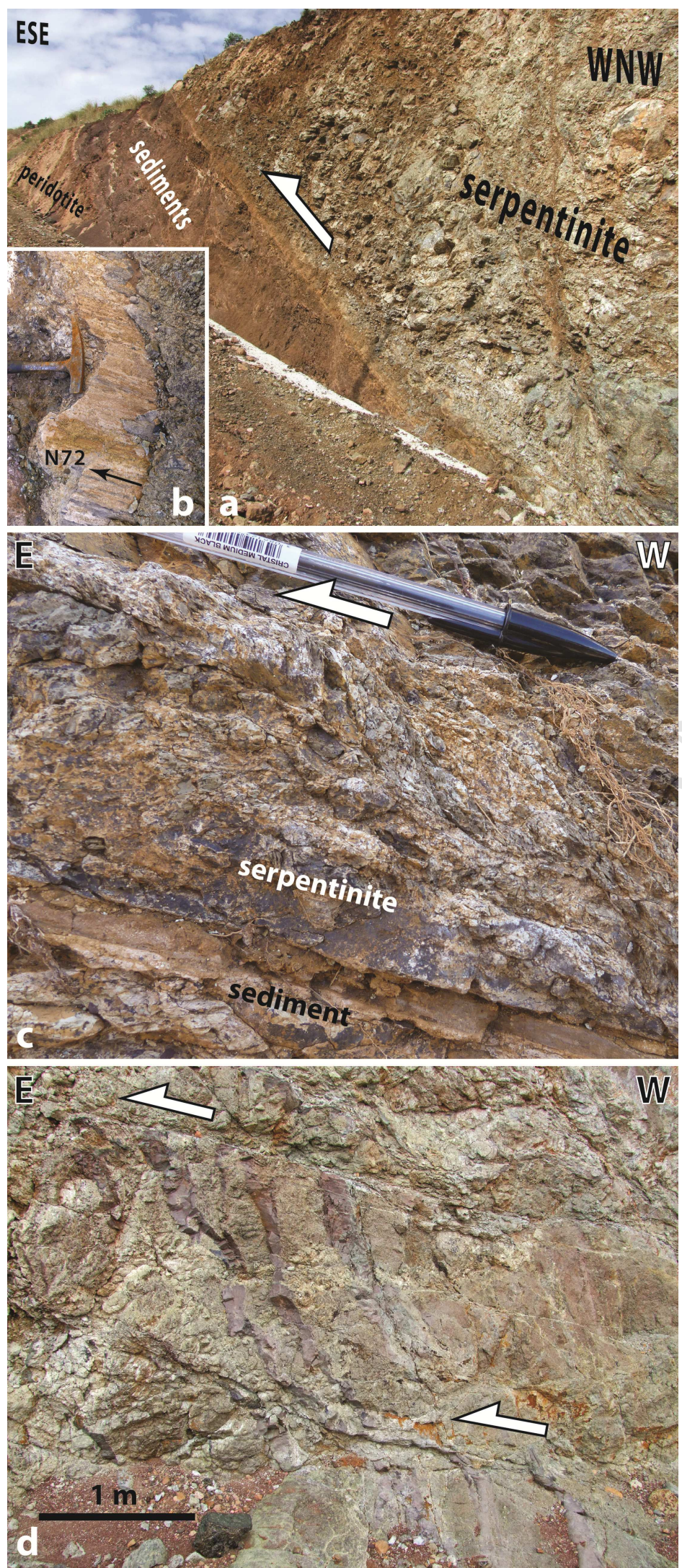


\section{ACCEPTED MANUSCRIPT}
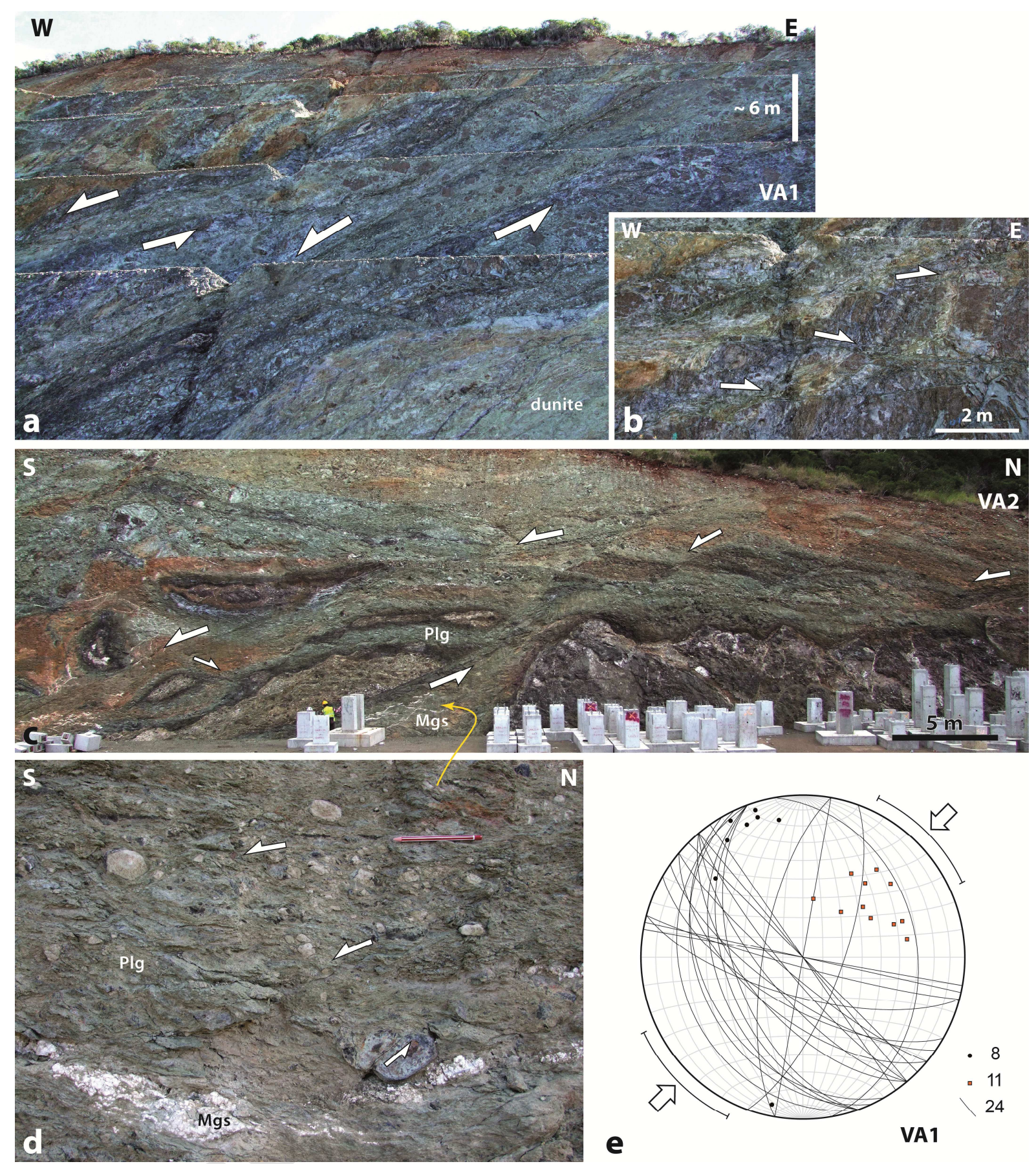


\section{ACCEPTED MANUSCRIPT}
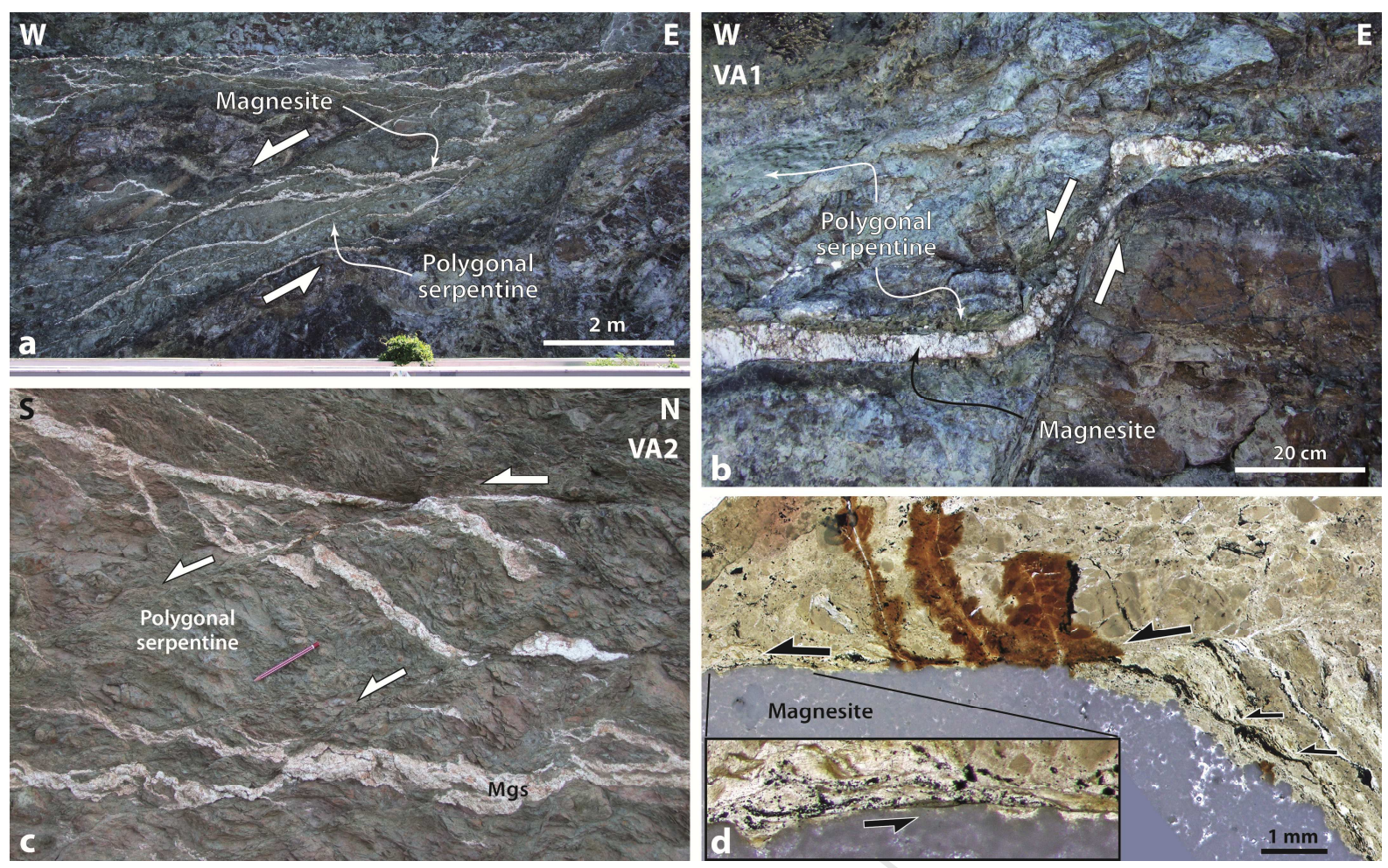


\section{ACCEPTED MANUSCRIPT}

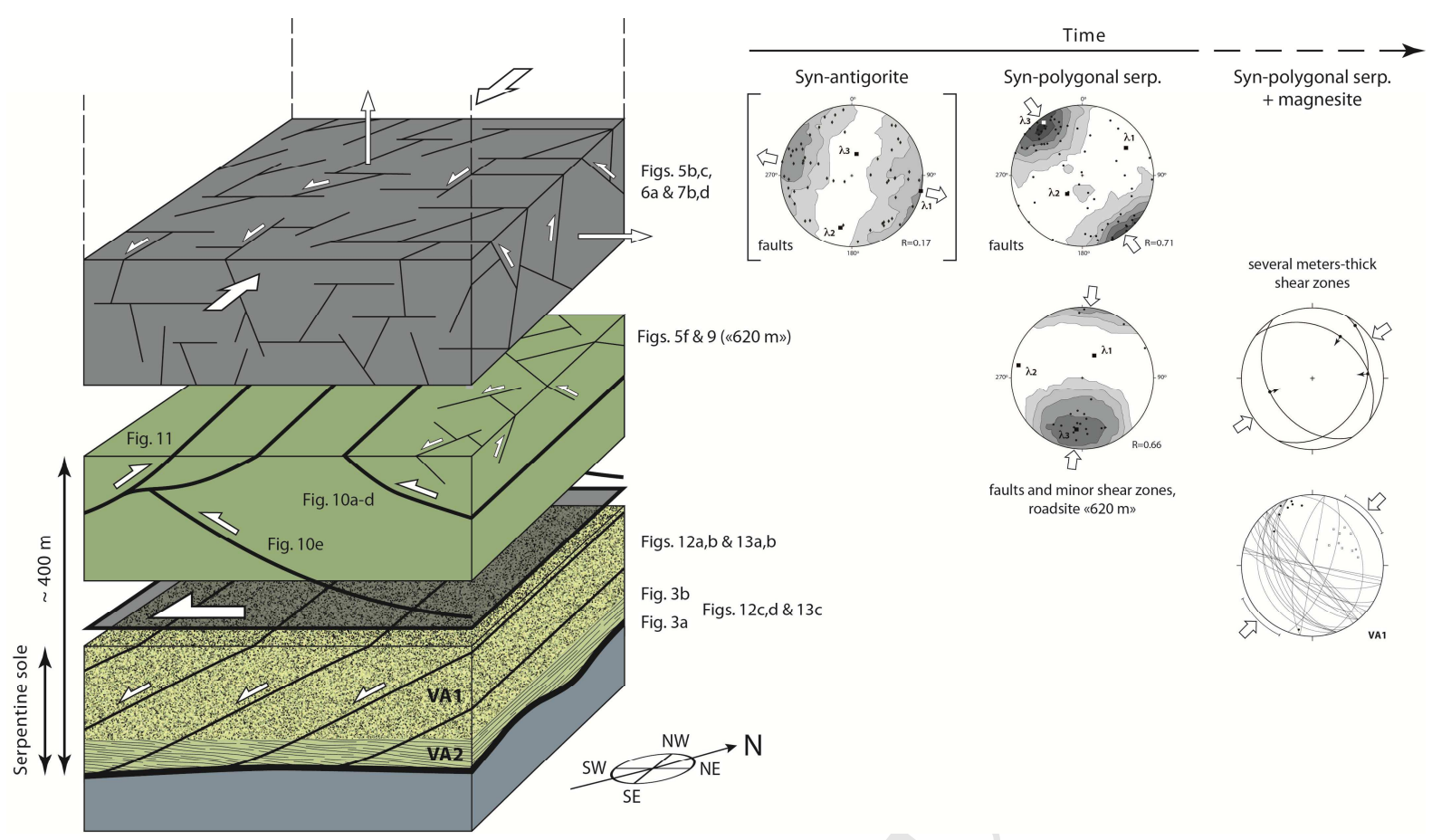




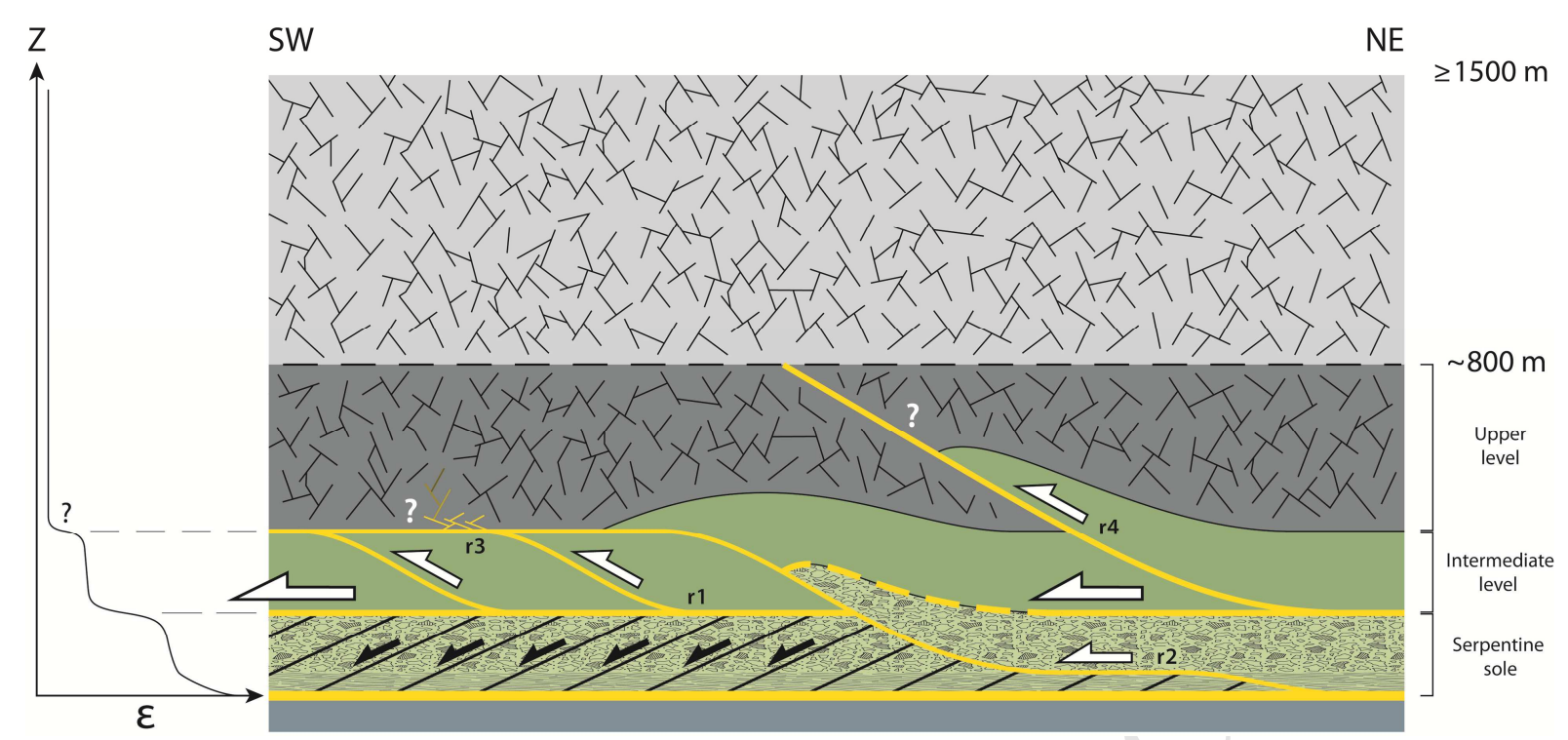


- We study the deformation associated with serpentines in the New Caledonia ophiolite

- Structural analysis is coupled with mineralogical characterization

- The evolution of deformation through space and time is described

- The reason for strain localization along the sole of the nappe is discussed 